\title{
Evaluation of coral reef carbonate production models at a global scale
}

\author{
N. S. Jones ${ }^{1}$, A. Ridgwell ${ }^{1}$, and E. J. Hendy ${ }^{2,3}$ \\ ${ }^{1}$ School of Geographical Sciences, University of Bristol, Bristol BS8 1SS, UK \\ ${ }^{2}$ School of Earth Sciences, University of Bristol, Bristol BS8 1RJ, UK \\ ${ }^{3}$ School of Biological Sciences, University of Bristol, Bristol BS8 1UG, UK \\ Correspondence to: E. J. Hendy (e.hendy@bristol.ac.uk)
}

Received: 7 August 2014 - Published in Biogeosciences Discuss.: 8 September 2014

Revised: 22 January 2015 - Accepted: 26 January 2015 - Published: 4 March 2015

\begin{abstract}
Calcification by coral reef communities is estimated to account for half of all carbonate produced in shallow water environments and more than $25 \%$ of the total carbonate buried in marine sediments globally. Production of calcium carbonate by coral reefs is therefore an important component of the global carbon cycle; it is also threatened by future global warming and other global change pressures. Numerical models of reefal carbonate production are needed for understanding how carbonate deposition responds to environmental conditions including atmospheric $\mathrm{CO}_{2}$ concentrations in the past and into the future. However, before any projections can be made, the basic test is to establish model skill in recreating present-day calcification rates. Here we evaluate four published model descriptions of reef carbonate production in terms of their predictive power, at both local and global scales. We also compile available global data on reef calcification to produce an independent observationbased data set for the model evaluation of carbonate budget outputs. The four calcification models are based on functions sensitive to combinations of light availability, aragonite saturation $\left(\Omega_{\mathrm{a}}\right)$ and temperature and were implemented within a specifically developed global framework, the Global Reef Accretion Model (GRAM). No model was able to reproduce independent rate estimates of whole-reef calcification, and the output from the temperature-only based approach was the only model to significantly correlate with coral-calcification rate observations. The absence of any predictive power for whole reef systems, even when consistent at the scale of individual corals, points to the overriding importance of coral cover estimates in the calculations. Our work highlights the need for an ecosystem modelling approach,
\end{abstract}

accounting for population dynamics in terms of mortality and recruitment and hence calcifier abundance, in estimating global reef carbonate budgets. In addition, validation of reef carbonate budgets is severely hampered by limited and inconsistent methodology in reef-scale observations.

\section{Introduction}

Coral reefs are the product of long-term $\mathrm{CaCO}_{3}$ accretion by calcifying organisms of the reef community (e.g. Hatcher, 1997; Perry et al., 2008), principally scleractinian corals and crustose coralline algae (CCA; e.g. Chave et al., 1972; Barnes and Chalker, 1990; Kleypas and Langdon, 2006; Mallela, 2007; Vroom, 2011). Coral reefs persist where net $\mathrm{CaCO}_{3}$ accretion is achieved, i.e. where calcification by reef organisms exceeds dissolution and bioerosion (reviewed by Kleypas and Langdon, 2006; Fig. 1; Perry, 2011). Globally, coral reef calcification accounts for $\sim 50 \%$ of shallow water (neritic) $\mathrm{CaCO}_{3}$ production (Milliman, 1993) with an estimated budget of $0.65-0.83 \mathrm{Pg}$ of $\mathrm{CaCO}_{3}$ each year (Vecsei, 2004). Most of this annual global carbonate production $\left(G_{\text {global }}\right)$ is preserved and buried, and so coral reefs play an important role in global carbon cycling (Vecsei, 2004) and hence the control of atmospheric $\mathrm{CO}_{2}$.

Although the precise mechanisms by which calcification occurs in both corals and coralline algae are still poorly understood (reviewed by Allemand et al., 2011), it is thought that the rate of calcification is environmentally modulated by some combination of seawater aragonite saturation state $\left(\Omega_{\mathrm{a}}\right)$, temperature and light availability (Buddemeier and 


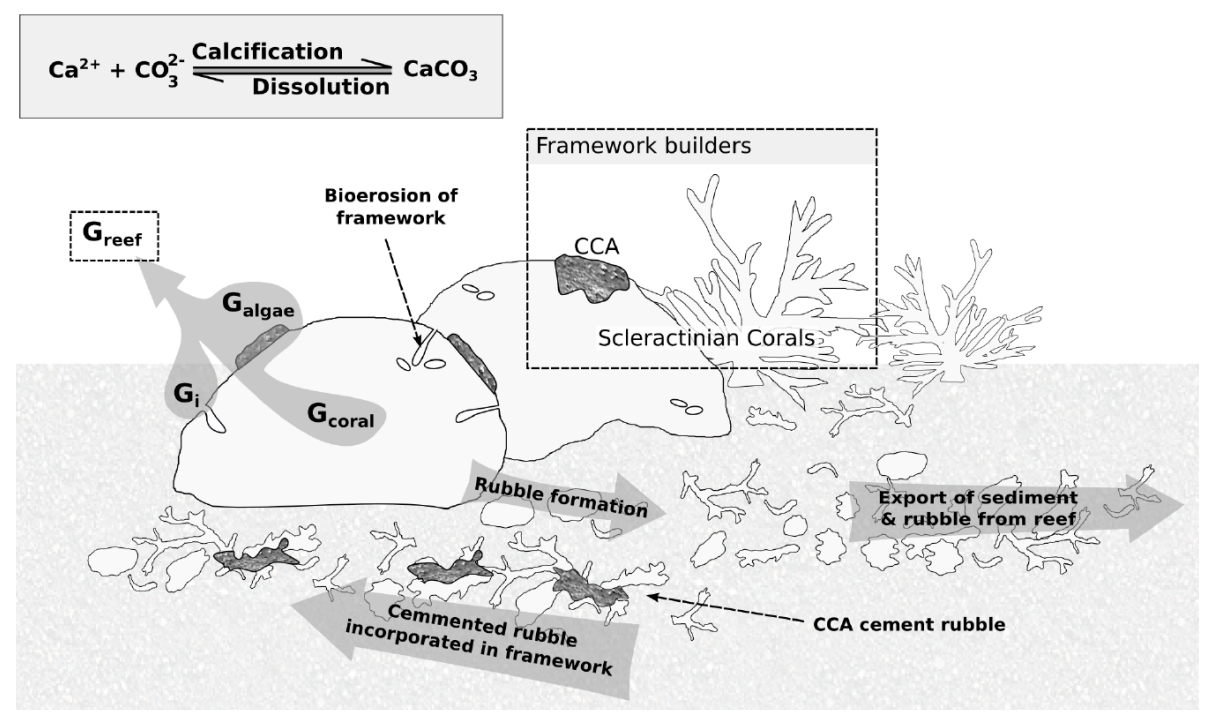

Figure 1. Schematic illustrating the coral reef carbonate budget and the modelled parameters ( $G_{\text {reef }}$ and $\left.G_{\text {coral }}\right)$ used to quantify carbonate production. Carbonate framework is principally produced by scleractinian corals $\left(G_{\text {coral }}\right)$ and crustose coralline algae $\left(C C A ; G_{\text {algae }}\right)$; the abiotic (inorganic) precipitation of carbonate cements $\left(G_{\mathrm{i}}\right)$ also occurs. Bioeroders break down the reef framework internally (e.g. worms, sponges) and externally (e.g. parrot fish, crown-of-thorns starfish). The rubble produced is incorporated back into the framework, by cementation or burial, or exported from the reef. The observational data available to test models of carbonate budget include $G_{\text {coral }}$ measured from coral cores, and $G_{\text {reef }}$ calculated from a reef community census or the total alkalinity of surrounding seawater.

Kinzie, 1976; Kleypas and Langdon, 2006; Tambutté et al., 2011). As a result, it is anticipated that calcification on coral reefs is sensitive to climate change and ocean acidification (e.g. Kleypas et al., 1999; Erez et al., 2011; Hoegh-Guldberg, 2011) - in particular the reduction of $\Omega_{\mathrm{a}}$ due to ocean acidification causing decreased calcification of individual corals (reviewed by Kleypas and Yates, 2009; Andersson and Gledhill, 2013) and coralline algae (e.g. Anthony et al., 2008; Johnson and Carpenter, 2012; Johnson et al., 2014), and rising sea surface temperatures causing an increase in coral bleaching frequency due to heat stress (e.g. Donner et al., 2005; Baker et al., 2008; Frieler et al., 2013).

The global reef carbonate budget (i.e. $G_{\text {global }}$ ) is inherently difficult to evaluate because it is impossible to empirically measure this variable; instead it must be extrapolated from reef-scale observations. Vecsei (2004) synthesized census-based measurements to produce values of reef calcification rates $\left(G_{\text {reef }}\right.$ Fig. 1$)$ - that varied both regionally and with depth - to estimate $G_{\text {global }}\left(0.65-0.83 \mathrm{Pg} \mathrm{yr}^{-1}\right)$. In contrast, the earlier estimate of $G_{\text {global }}\left(0.9 \mathrm{Pg} \mathrm{yr}^{-1}\right)$ from Milliman (1993) is calculated from two modal values for $G_{\text {reef }}$ (reefs: $0.4 \mathrm{~g} \mathrm{~cm}^{-2} \mathrm{yr}^{-1}$, lagoons: $0.08 \mathrm{~g} \mathrm{~cm}^{-2} \mathrm{yr}^{-1}$ ). Opdyke and Walker (1992) found a lower estimate of reefal $\mathrm{CaCO}_{3}$ budget of $1.4 \mathrm{Pg} \mathrm{yr}^{-1}$ derived from published Holocene $\mathrm{CaCO}_{3}$ accumulation rates. Census-based methods calculate $G_{\text {reef }}$ by summing the calcification by each reef-calcifier, multiplied by its fractional cover of the reef substrate (Chave et al., 1972; Perry et al., 2008). The calcification by individual components of the reef community may be derived from linear extension rates or published values for representative species (Vecsei, 2004). Often it is only calcification by scleractinian corals $\left(G_{\text {coral }}\right)$ and coralline algae $\left(G_{\text {algae }}\right)$ that are considered, due to their dominance in $\mathrm{CaCO}_{3}$ production (e.g. Stearn et al., 1977; Eakin, 1996; Harney and Fletcher, 2003). Calcification rates for portions of a reef (e.g. reef flat or back reef) can also be calculated from the total alkalinity change $\left(\Delta A_{\mathrm{T}}\right)$ of seawater (e.g. Silverman et al., 2007; Shamberger et al., 2011; Albright et al., 2013). This is because precipitation of $\mathrm{CaCO}_{3}$ decreases the total alkalinity $\left(A_{\mathrm{T}}\right)$ of seawater whereas dissolution has the opposite effect. This alkalinity anomaly technique was first used in a reef setting in the 1970s (Smith and Pesret, 1974; Smith and Kinsey, 1976) and has since been used to estimate basin-scale pelagic and coral reef calcification (Steiner et al., 2014). $G_{\text {reef }}$ is calculated by measuring the change in $A_{\mathrm{T}}$ over a discrete time interval $(\Delta t)$; because the change in $A_{\mathrm{T}}$ includes dissolution the calcification measured is net ecosystem calcification (NEC) or net $G_{\text {reef }}$ (Eq. 1; Albright et al., 2013):

$G_{\text {reef }}=-0.5 \cdot p z \frac{\Delta A_{\mathrm{T}}}{\Delta t}$

where $p$ is seawater density $\left(\mathrm{kg} \mathrm{m}^{-3}\right)$ and $z$ is water depth (m). $G_{\text {reef }}$ measured using $\Delta A_{\mathrm{T}}$ accounts for inorganic precipitation $\left(G_{\mathrm{i}}\right.$; Fig. 1) and dissolution; however, unlike census-based methods for calculating $G_{\text {reef }}$, it is not possible to break down the contribution of individual calcifiers in the reef community (Perry, 2011). $G_{\text {coral }}$ calculated from the width and density of annual bands within the colony skele- 
Table 1. Summary of calcification models implemented in the global reef accretion model (GRAM) framework.

\begin{tabular}{|c|c|c|c|c|}
\hline Model & ReefHab & KAG & LOUGH & SILCCE \\
\hline Source & Kleypas (1997) & Kleypas et al. (2011) & Lough (2008) & Silverman et al. (2009) \\
\hline $\begin{array}{l}\text { Application or } \\
\text { Formulation }\end{array}$ & $\begin{array}{l}\text { Predicting changes } \\
\text { to reef habitat extent, } \\
\text { globally, since last } \\
\text { glacial maximum. }\end{array}$ & $\begin{array}{l}\text { Seawater carbonate } \\
\text { chemistry changes on } \\
\text { a transect in Moorea, } \\
\text { French Polynesia }{ }^{a} \text {. }\end{array}$ & $\begin{array}{l}\text { Derived from coral } \\
\text { core (Porites sp.) } \\
\text { measurements and } \\
\text { temperature form } \\
\text { the HadISST data set } \\
\text { (Rayner et al., 2003). }\end{array}$ & $\begin{array}{l}\text { Future climate } \\
\text { simulations at reef } \\
\text { locations provided by } \\
\text { ReefBase }^{b} \text {. }\end{array}$ \\
\hline Scale applied & Global & Reef & Colony & Reef/Global \\
\hline$E_{\text {surf }}$ & $\checkmark$ & $\checkmark$ & - & - \\
\hline$\Omega_{\mathrm{a}}$ & - & $\checkmark$ & - & $\checkmark$ \\
\hline SST & - & - & $\checkmark$ & $\checkmark$ \\
\hline Units & $\mathrm{mm} \mathrm{m}^{-2} \mathrm{yr}^{-1}$ & $\mathrm{mmol} \mathrm{m}{ }^{-2} \mathrm{~h}^{-1}$ & $\mathrm{~g} \mathrm{~cm}^{-2} \mathrm{yr}^{-1}$ & $\mathrm{mmol} \mathrm{m}^{-2} \mathrm{yr}^{-1}$ \\
\hline
\end{tabular}

${ }^{a}$ Model output was compared to alkalinity changes measured in situ at Moorea by Gattuso et al. $(1993,1996,1997)$ and Boucher et al. (1998). ${ }^{b}$ ReefBase: A Global Information System for Coral Reefs (http://www.reefbase.org).

ton is commonly used in census-based observations of $G_{\text {reef }}$ (Fig. 1; Knutson et al., 1972).

Estimates of $G_{\text {global }}$ alone tell us little about how reefs will be affected by climate change at a global scale. Instead, if coral calcification $\left(G_{\text {coral }}\right)$ and reef community calcification rates $\left(G_{\text {reef }}\right)$ can be numerically modelled as a function of the ambient physicochemical environment (e.g. irradiance $(E), \Omega_{\mathrm{a}}$ and temperature), then the results could be scaled up to produce an estimate of $G_{\text {global }}$ that could be recalculated as global environmental conditions change. Examples of this approach (Table 1) include: (1) Kleypas (1997; "ReefHab"), which is sensitive to $E$ only and was initially developed to predict global reef calcification $\left(G_{\text {global }}\right)$ and habitat area and used to estimate changes in $G_{\text {global }}$ since the Last Glacial Maximum; (2) Kleypas, Anthony and Gattuso (2011; "KAG"), which simulates $G_{\text {reef }}$ as a function of $E$ and $\Omega_{\mathrm{a}}$ and was originally developed to simulate carbonate chemistry changes in seawater on a reef transect; (3) Lough (2008; "LOUGH") which simulates $G_{\text {coral }}$ as a function of sea surface temperature (SST) and was derived from the strong relationship observed between SST and $G_{\text {coral }}$ in massive Porites sp. colonies from the Great Barrier Reef (GBR), Arabian Gulf and Papua New Guinea; and (4) Silverman, Lazar, Cao, Caldeira and Erez (2009; "SILCCE"), which simulates $G_{\text {reef }}$ as a function of SST and $\Omega_{\mathrm{a}}$ and was used to simulate the effects of projected future SSTs and $\Omega_{\mathrm{a}}$ at known reef locations globally. Although further models exist describing $G_{\text {coral }}$ as a function of carbonate ion concentration ( $\left[\mathrm{CO}_{3}^{2-}\right]$; Suzuki et al., 1995; Nakamura and Nakamori, 2007) these are synonymous to the $\Omega_{\mathrm{a}}$ function used in KAG and SILCCE. With the exception of Kleypas et al. (2011), which included classes of non-calcifying substrate, the above models do not account for community composition. Reef calcification rates vary considerably depending on the abundance of corals and coralline algae (Gattuso et al., 1998). Therefore, successful up-scaling of $G_{\text {reef }}$ and $G_{\text {coral }}$ to estimate $G_{\text {global }}$ also requires, as a minimum, quantifying live coral cover (LCC).

To date it remains to be demonstrated that any of the published models reproduce present-day reef calcification rates (i.e. $G_{\text {reef }}$ ). Despite this, simulations of the effects of future climate scenarios have been attempted using calcification rate models. For example, McNeil et al. (2004) incorporated LOUGH with the linear relationship observed between $\Omega_{\mathrm{a}}$ and calcification in the BioSphere 2 project (Langdon et al., 2000), and predicted that $G_{\text {reef }}$ will increase in the future. In contrast, a similar study by Silverman et al. (2009; SILCCE) concluded that coral reefs will start to dissolve. Whilst McNeil's study was criticized for its incorrect underlying assumptions (Kleypas et al., 2005), the contradictory predictions from these two models highlights the importance of comparing and fully evaluating reef calcification models, starting with their performance against present-day observations.

Here we describe a novel model framework, the global reef accretion model (GRAM), and evaluate the four previously published calcification models (ReefHab, KAG, LOUGH and SILCCE) in terms of their skill in predicting $G_{\text {coral }}$ and $G_{\text {reef }}$. The independent evaluation data set comprises observations of $G_{\text {reef }}$ from census-based methods and $\Delta A_{\mathrm{T}}$ experiments as well as $G_{\text {coral }}$ measured from coral cores. The individual model estimates of $G_{\text {global }}$ are discussed in comparison with previous empirical estimates. We highlight where model development is required in order to accurately simulate the effects of past and future environmental conditions on calcification rates in coral reefs. 
Table 2. Environmental data description (variable name, units, temporal and spatial resolution), and their sources, used to produce the physico-chemical domain mask (ranges shown) and force the calcification models (ReefHab, KAG, LOUGH and SILCCE) in the global reef accretion model (GRAM) framework.

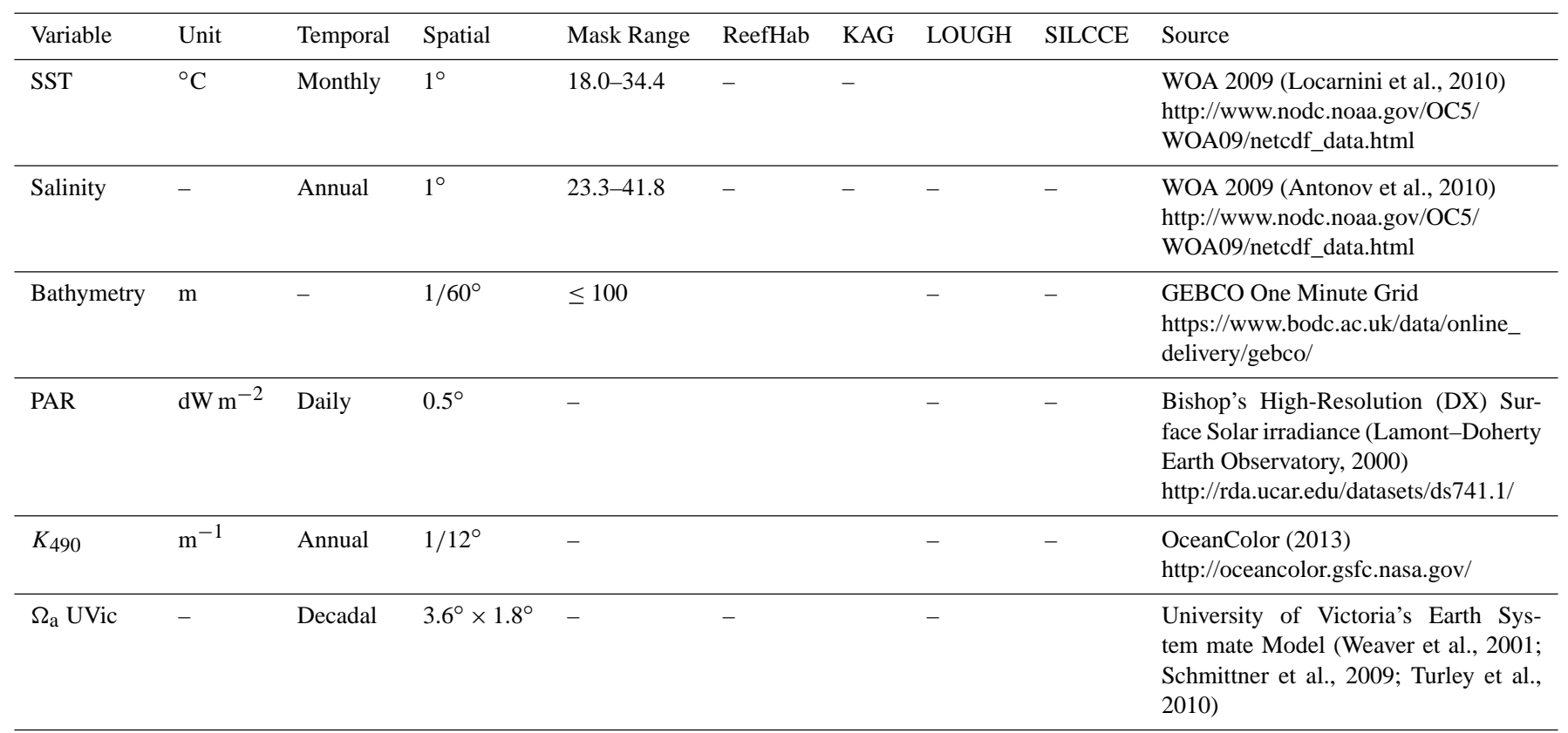

SST - sea surface temperature; WOA - World Ocean Atlas; GEBCO - general bathymetric chart of the Oceans; BODC - British Oceanographic Data Centre; PAR - surface photosynthetically available radiation; $K_{490}-490 \mathrm{~nm}$ light attenuation coefficient; $\Omega_{\mathrm{a}}-$ aragonite saturation.

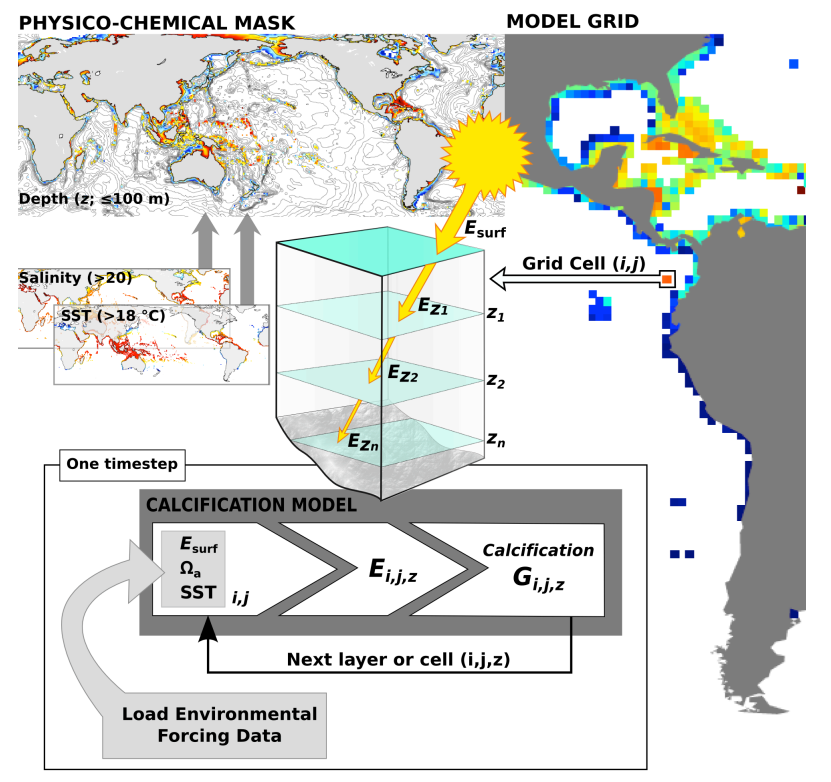

Figure 2. Schematic of logical steps at each time step within GRAM. GRAM's domain is defined by a bathymetric and physicochemical mask within which calcification is calculated, at each time step and in every domain grid cell, according to the calcification model used. Where calcification is modelled as a function of light, the availability of light at depth $\left(E_{z}\right)$ is calculated for each model layer $\left(z_{i}\right)$.

\section{Methods}

\subsection{Model description}

Four calcification models were selected for evaluation in global-scale simulations: (1) ReefHab (Kleypas, 1997), (2) KAG (Kleypas et al., 2011), (3) LOUGH (Lough, 2008) and (4) SILCCE (Silverman et al., 2009; Table 2). Previous applications for these models cover a hierarchy of spatial scales (colony, LOUGH; reef, KAG and global, ReefHab and SILCCE) as well as representing different approaches for measuring $G_{\text {coral }}$ (Fig. 1; LOUGH) and $G_{\text {reef }}$ (Fig. 1; ReefHab, KAG and SILCCE). Any modifications of the models from their published form are described below, and these are only made where necessary to fit them into the same GRAM framework (Fig. 2).

\subsubsection{ReefHab}

Kleypas (1997) developed ReefHab to predict changes in the global extent of reef habitat since the last Glacial Maximum (Kleypas, 1997). Like photosynthesis, calcification is light saturated (Allemand et al., 2011); as the rate of calcification increases toward a maximum value, it becomes light saturated after irradiance increases beyond a critical value. This curvilinear relationship can be described with various functions - however, hyperbolic tangent and exponential functions have been found to best describe the relation- 
ship (Chalker, 1981). The ReefHab model calculates vertical accretion $\left(G_{\text {reef }}\right.$ in $\left.\mathrm{cm} \mathrm{m}^{-2} \mathrm{~d}^{-1}\right)$ as a function of irradiance at the depth of the seabed $\left(E_{z}\right)$ and maximum growth rate $\left(G_{\max }=1 \mathrm{~cm} \mathrm{yr}^{-1}\right)$. The hyperbolic tangent function uses a fixed light saturation constant $\left(E_{\mathrm{k}}=250 \mu \mathrm{mol} \mathrm{m}^{-2} \mathrm{~s}^{-1}\right)$ to generate a scaling factor for $G_{\max }$ (Eq. 2):

$G_{\text {reef }}=G_{\max } \cdot \tanh \left(\frac{E_{z}}{E_{k}}\right) \cdot \mathrm{TF} \quad E_{z}>E_{\mathrm{c}}$

where $E_{z}$ is derived from the surface irradiance $\left(E_{\text {surf }}\right)$ and the inverse exponent of the product of the light attenuation coefficient $\left(K_{490}\right)$ and depth $(z ;$ Eq. 3). Following the methodology in Kleypas (1997), if $E_{z}$ is less than the minimum irradiance necessary for calcification $\left(250 \mu \mathrm{mol} \mathrm{m}^{-2} \mathrm{~s}^{-1}\right) G_{\text {reef }}=0 \mathrm{~cm} \mathrm{~m}^{-2} \mathrm{~d}^{-1}$. TF is the topography factor (Eq. 4), which reduces $G_{\text {reef }}$ in areas of low topographic relief:

$E_{z}=E_{\text {surf }} \cdot e^{-K_{490} z}$

$\mathrm{TF}=\frac{\ln (\alpha \cdot 100)}{5}$

where $\alpha$ is calculated from a nine-cell neighbourhood (centre index 2.2) by summing the inverse tangent of the difference between cell depths $\left(z_{i, j}-z_{2.2}\right)$ divided by the distance between cell centres $\left(D_{i, j-2.2}\right)$ :

$\alpha=\sum_{i=1}^{3} \sum_{j=1}^{3} \frac{\tan ^{-1} z_{i, j}-z_{2.2}}{D_{i, j-2.2}}$

Vertical accretion $\left(\mathrm{cm} \mathrm{m}^{-2} \mathrm{~d}^{-1}\right)$ is converted to $\mathrm{g}\left(\mathrm{CaCO}_{3}\right)$ $\mathrm{cm}^{-2} \mathrm{~d}^{-1}$ by multiplying average carbonate density $\left(2.89 \mathrm{~g} \mathrm{~cm}^{-3}\right)$ and porosity $(50 \%)$ as defined by Kleypas (1997).

\subsubsection{KAG}

Anthony et al. (2011) performed laboratory flume incubations on Acropora aspera to parameterize the relationship between (day and night) calcification rates and $\Omega_{\mathrm{a}}$, determining the reaction order $(n)$ and maximum calcification rates ( $k_{\text {day }}$ and $k_{\text {night }}$ ). The resultant model was then implemented by Kleypas et al. (2011), with the addition of an exponential light-sensitive function that accounted for light-enhanced calcification, to simulate seawater chemistry changes along a reef transect at Moorea, French Polynesia. The transect did not exceed $2 \mathrm{~m}$ in depth; therefore, it was appropriate to use the surface irradiance ( $\left.E_{\text {surf }}\right)$ for the calculation of $G_{\text {reef. }}$ In this study $G_{\text {reef }}$ is calculated (Eq. 6) using $E_{z}$ (Eq. 3) rather than $E_{\text {surf }}$ because the maximum depth in the model domain is $100 \mathrm{~m}$, greatly exceeding the depth of the original application:

$G_{\text {reef }}=\left(G_{\max }\left(1-e^{-E_{z} / E_{k}}\right)^{n}+G_{\mathrm{dark}}\right) \cdot A_{\mathrm{c}}$ where $A_{\mathrm{c}}$ is the fractional cover of live coral (i.e. $A_{\mathrm{c}}=1$ when coral cover is $100 \%)$. Here $E_{\mathrm{k}}$ is greater than in ReefHab $\left(400 \mu \mathrm{mol} \mathrm{m}^{-2} \mathrm{~s}^{-1}\right.$ versus $\left.250 \mu \mathrm{mol} \mathrm{m}^{-2} \mathrm{~s}^{-1}\right)$ following the parameterization used by Kleypas et al. (2011). $G_{\text {reef }}$ is calculated here in $\mathrm{mmol} \mathrm{m} \mathrm{m}^{-2} \mathrm{~d}^{-1}$ and is divided into day and night rates $\left(G_{\max }\right.$ and $\left.G_{\text {dark }}\right)$; both are calculated as a function of $\Omega_{\mathrm{a}}$. For this study it was necessary to introduce day length $\left(L_{\text {day }} ; \mathrm{h}\right)$ to Eq. (7) and Eq. (8) because of the daily time step as opposed to the hourly time step of the original model:

$G_{\max }=k_{\text {day }}\left(\Omega_{\mathrm{a}}-1\right)^{n} L_{\text {day }}$

$G_{\text {dark }}=k_{\text {dark }}\left(\Omega_{\mathrm{a}}-1\right)^{n}\left(24-L_{\text {day }}\right)$

$L_{\text {day }}$ was calculated using the method described by Haxeltine and Prentice (1996), which uses Julian day $\left(J_{\mathrm{d}}\right)$ and latitude (lat) as follows:
$L_{\text {day }}=0$
$u \leq v$
$L_{\text {day }}=24 \cdot \frac{\cos ^{-1} \cdot(-u / v)}{2 \pi}$
$u>-v, u<v$
$L_{\text {day }}=24$
$u \geq v$

where the variables $u$ and $v$ are calculated from lat and aa (a function of $J_{\mathrm{d}}$; Eq. 14):

$u=\sin ($ lat $) \cdot(\mathrm{aa})$

$v=\cos ($ lat $) \cdot \cos (\mathrm{aa})$

$a a=-23.4^{o} \cdot \cos \left(\frac{360\left(J_{\mathrm{d}}+10\right)}{365}\right)$

$\mathrm{CaCO}_{3}$ production in $\mathrm{mmol} \mathrm{m}^{-2} \mathrm{~d}^{-1}$ was converted to $\mathrm{g} \mathrm{cm}^{-2} \mathrm{~d}^{-1}$ using the molecular weight of $\mathrm{CaCO}_{3}$ $(\mathrm{MR}=100)$.

\subsubsection{LOUGH}

ReefHab and KAG were both derived from theoretical understanding of the process of calcification and parameterized by values observed in the literature or in situ. In contrast, LOUGH was derived from the observed relationship between annual calcification rates of massive Porites sp. colonies and local SST (Lough, 2008). A linear relationship (Eq. 15) was fitted to data from 49 reef sites from the Great Barrier Reef (GBR; Lough and Barnes, 2000), Arabian Gulf and Papua New Guinea (Lough, 2008), and accounted for $85 \%$ of the variance $(p<0.001)$ :

$G_{\text {coral }}=\frac{0.327 \cdot \mathrm{SST}-6.98}{365}$

Division by 365 days is necessary here to adapt the original model to the daily time step used in this study and results in $G_{\text {coral }}$ in $\mathrm{g} \mathrm{cm}^{-2} \mathrm{~d}^{-1}$. 


\subsubsection{SILCCE}

Using the alkalinity anomaly technique $\left(\Delta A_{\mathrm{T}}\right)$, Silverman et al. (2007) found a correlation between rates of inorganic precipitation $\left(G_{\mathrm{i}}\right)$ and net $G_{\text {reef }}\left(\mathrm{mmol} \mathrm{m}^{-2} \mathrm{~d}^{-1}\right)$. Silverman et al. (2009) fitted observations to Eq. (16) to calculate $G_{\mathrm{i}}$ as a function of $\Omega_{\mathrm{a}}$ and SST (Eq. 17):

$G_{\mathrm{i}}=k_{\mathrm{SST}}\left(\Omega_{a}-1\right)^{n_{\mathrm{SST}}}$

$G_{\mathrm{i}}=\frac{24}{1000}\left(-0.0177 \cdot \mathrm{SST}^{2}+1.4697 \cdot \mathrm{SST}+14.893\right)$

$\left(\Omega_{\mathrm{a}}-1\right)^{(0.0628 \cdot \mathrm{SST}+0.0985)}$

Incorporating Eq. (17) with SST and $\Omega_{\mathrm{a}}$ sensitivity of coral calcification gives

$G_{\text {reef }}=k_{r}^{\prime} \cdot G_{\mathrm{i}} \cdot e^{-\left(k_{p}^{\prime}\left(\mathrm{SST}-T_{\mathrm{opt}}\right) / \Omega_{\mathrm{a}}^{2}\right)^{2}} \cdot A_{\mathrm{c}}$

where $k_{r^{\prime}}\left(38 \mathrm{~m}^{2} \mathrm{~m}^{-2}\right)$ and $k_{p^{\prime}}\left(1^{\circ} \mathrm{C}^{-1}\right)$ are coefficients controlling the amplitude and width of the calcification curve. $T_{\mathrm{opt}}$ is the optimal temperature of calcification and is derived from summer temperatures in the WOA 2009 monthly average SST (Locarnini et al., 2010): June (in the Northern Hemisphere) and December (in the Southern Hemisphere). Again, $\mathrm{CaCO}_{3}$ production in $\mathrm{mmol} \mathrm{m}^{-2} \mathrm{~d}^{-1}$ was converted to $\mathrm{g} \mathrm{cm}^{-2} \mathrm{~d}^{-1}$ using the molecular weight of $\mathrm{CaCO}_{3}(\mathrm{MR}=100)$.

\subsubsection{Global reef accretion model (GRAM) framework}

The calcification production models above were implemented within our global reef accretion model (GRAM) framework. In this study, GRAM was implemented on a $0.25^{\circ} \times 0.25^{\circ}$ global grid. Vertically, the model domain was resolved with 10 depth levels at equal $10 \mathrm{~m}$ intervals with the fraction, by area, of a model cell (quasi-seabed) within each $10 \mathrm{~m}$ layer recorded for calculating total $\mathrm{CaCO}_{3}$ production (Fig. 2). A physicochemical mask was imposed to limit $\mathrm{CaCO}_{3}$ production to shallow-water tropical and subtropical areas. This mask was defined following Kleypas (1997; Kleypas et al., 1999): SST $\left(>18^{\circ} \mathrm{C}\right)$, salinity (23.3$41.8)$ and depth $(\leq 100 \mathrm{~m})$. Calcification was calculated on a daily basis over the course of 1 full calendar year and according to the environmental conditions at each grid cell (described below).

\subsection{Input data description}

Table 1 lists the data used to force GRAM. Ocean bathymetry was calculated from GEBCO One Minute data set (https: //www.bodc.ac.uk/data/online_delivery/gebco/) and mapped to the model grid. Monthly values for SST (Locarnini et al., 2010) and salinity (Antonov et al., 2010) were obtained from the World Ocean Atlas (WOA) 2009. These climatologies are reanalysis products of observations collected 1955-2009.
The WOA data have a scaled vertical resolution with 24 layers, with a maximum depth of $1400 \mathrm{~m}$; however, only surface values were used in this study. Daily photosynthetically available radiation (PAR), for the period 1991-1993, were obtained from Bishop's High-resolution (DX) surface solar irradiance data (Lamont-Doherty Earth Observatory, 2000) derived from the International Satellite Cloud Climatology Project (ISCCP) data (Bishop and Rossow, 1991; Bishop et al., 1997). Following Kleypas (1997), units of $\mathrm{dW} \mathrm{m}^{-2}$ were converted to $\mu \mathrm{mol} \mathrm{m}{ }^{-2} \mathrm{~s}^{-1}$ by multiplying by a factor of 0.46 . The monthly diffuse light attenuation coefficient of $490 \mathrm{~nm}$ light $\left(K_{490}\right)$ was obtained from the Level-3 binned MODIS-Aqua products in the OceanColor database (available at: http://oceancolor.gsfc.nasa.gov). Surface $\Omega_{\mathrm{a}}$ was derived from the University of Victoria's Earth System Climate Model (Schmittner et al., 2009; Turley et al., 2010) for the decade 1990-2000. All input data were converted, without interpolating, to the same resolution as the model by recording the closest data point to the coordinates of the model grid cell's centre. Missing values were extrapolated as an unweighted mean from the nearest values in the data set found in the model cell's neighbourhood (including diagonals) in an area up to $1^{\circ}$ from the missing data point.

\subsection{Evaluation data set and methodology}

An independent data set of in situ measured calcification rates $\left(G_{\text {reef }}\right.$ and $\left.G_{\text {coral }}\right)$ was collated from the literature to evaluate model performance. In total, data from 11 coral core studies (Table 3; Montastrea and Porites sp.), 8 censusbased and $12 \Delta A_{\mathrm{T}}$ studies (Table 4) were assembled. This data set is not comprehensive of all studies that have measured $G_{\text {reef }}$ and $G_{\text {coral }}$; many older studies were excluded (e.g. Sadd, 1984) due to errors in calculation of $G_{\text {reef }}$ that were resolved by Hubbard et al. (1990). The studies sampled cover a representative range of SST and $\Omega_{\mathrm{a}}$ conditions in which present-day reefs are found (Fig. 3). The positions of the in situ measurements were used to extract the equivalent data points from the gridded model output. Where location coordinates were not reported, Google Earth (available at: http://earth.google.com) was used to establish the longitude and latitude, accurate to the model resolution of $0.25^{\circ}$. For uniformity, reported units of measurement were converted to $\mathrm{g}\left(\mathrm{CaCO}_{3}\right) \mathrm{cm}^{-2} \mathrm{yr}^{-1}$. The values of live coral cover (LCC) reported in the census-based and $\Delta A_{\mathrm{T}}$ studies were used to convert model $G_{\text {coral }}$ to $G_{\text {reef }}$. A global average of $30 \%$ (Hodgson and Liebeler, 2002) was used where LCC was not reported (Table 4).

Model skill in reproducing the observed data was assessed using simple linear regression analysis preformed on observed calcification rates paired with their equivalent model value. When testing LOUGH against coral core data, values that were used in the original formulation of the model (Lough, 2008) were excluded so as to preserve the independence of the data. Similarly, when correlating SILCCE with 
Table 3. Details of studies used for evaluating model calcification rates; observed coral calcification rates $\left(G_{\text {coral }}\right)$ derived from annual density banding in coral cores; - indicates fields that were not reported. Full data, including values of $G_{\text {coral }}$, are supplied in the Supplement. Studies are listed alphabetically by their ID.

\begin{tabular}{|c|c|c|c|c|c|c|c|}
\hline ID & Source & Sea/region & Genus & No. sites & Period observed & Latitude & Longitude \\
\hline $\mathrm{Ca}$ & Carricart-Ganivet and Merino (2001) & Gulf of Mexico & Montastrea & 6 & $1968-1991$ & 19.08 to 22.53 & 264.15 to 270.35 \\
\hline $\mathrm{Ch}$ & Chen et al. (2011) & South China Sea & Porites & 1 & - & 22.45 & 114.69 \\
\hline Co & Cooper et al. $(2012)^{\mathrm{a}}$ & Western Australia & Porites & 6 & $1900-2010$ & -28.47 to -17.27 & 113.77 to 119.37 \\
\hline Ed & Edinger et al. (2000) & Java Sea & Porites & 5 & 1986-1996 & -6.58 to -5.82 & 110.38 to 110.71 \\
\hline $\mathrm{Fa}$ & Fabricius et al. (2011) & Papua New Guinea & Porites & 3 & - & -9.83 to -9.74 & 150.82 to 150.88 \\
\hline $\mathrm{Gr}$ & Grigg (1982) & Hawaii & Porites & 14 & - & 19.50 to 28.39 & 181.70 to 204.05 \\
\hline Sc & Scoffin et al. (1992) & Thailand & Porites & 11 & 1984-1986 & 7.61 to 8.67 & 97.65 to 98.78 \\
\hline Sh & Shi et al. (2012) & South China Sea & Porites & 1 & $1710-2012$ & 9.90 & 115.54 \\
\hline
\end{tabular}

a Data were sourced from the Australian Institute of Marine Science (AIMS): AIMS (2014a) provides access to "De" data and AIMS (2014b) provides access to "Co" data. De data were used in the formulation of LOUGH (Lough, 2008) but subsequently published following further study (De'ath et al., 2009).

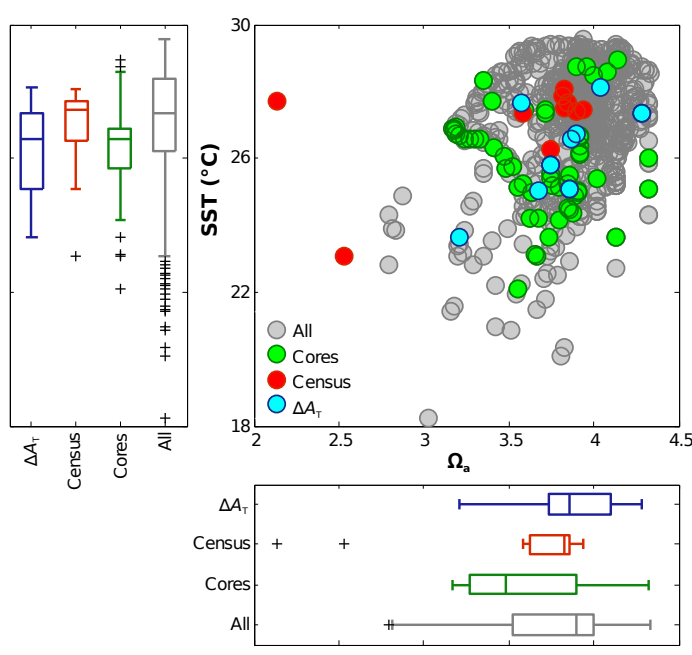

Figure 3. Distribution of sea surface temperatures (SST) and aragonite saturation $\left(\Omega_{\mathrm{a}}\right)$ at: (All) reef locations (ReefBase: A Global Information System for Coral Reefs. April, 2014. http://www. reefbase.org); (Cores) coral core data locations; (Census) censusbased and $\left(\triangle A_{\mathrm{T}}\right)$ alkalinity anomaly study locations. SST values are taken from WOA 2009 annual average values (Locarnini et al., 2010) and $\Omega_{\mathrm{a}}$ values are derived from UVic model (Weaver et al., 2001; Schmittner et al., 2009; Turley et al., 2010) output. The range, 25 th and 75th percentiles, median lines and outliers of SST and $\Omega_{\mathrm{a}}$ are displayed in the box and whisker plots.

$\Delta A_{\mathrm{T}}$ data, the Silverman et al. (2007) datum was excluded. A global average LCC of $30 \%$ (Hodgson and Liebeler, 2002) was applied to model $\mathrm{CaCO}_{3}$ production in model comparisons with census-based and $\Delta A_{\mathrm{T}} G_{\text {reef }}$ at a global scale. Global mean $G_{\text {reef }}$ and $G_{\text {global }}$ were calculated by applying a further $10 \%$ reefal area to model $\mathrm{CaCO}_{3}$ production; this follows the assumption in Kleypas (1997) that $90 \%$ of the seabed is composed of unsuitable substrate for reef colonization and growth. Global and regional values are compared directly to the most recent estimates by Vecsei (2004), although other global estimates are also considered.

\section{Results}

\subsection{Model carbonate production rates}

Globally averaged values of $G_{\text {reef }}$ (summarized in Table 5) vary little between ReefHab $\left(0.65 \pm 0.35 \mathrm{~g} \mathrm{~cm}^{-2} \mathrm{yr}^{-1}\right)$, KAG $\quad\left(0.51 \pm 0.21 \mathrm{~g} \mathrm{~cm}^{-2} \mathrm{yr}^{-1}\right) \quad$ and LOUGH $\left(0.72 \pm 0.35 \mathrm{~g} \mathrm{~cm}^{-2} \mathrm{yr}^{-1}\right)$, with SILCCE producing a somewhat smaller value $\left(0.21 \pm 0.11 \mathrm{~g} \mathrm{~cm}^{-2} \mathrm{yr}^{-1}\right)$. A consistent feature across all models is the high carbonate production in the southern Red Sea along the coast of Saudi Arabia and Yemen and, in KAG and LOUGH, the East African coast (Fig. 4). In all models, there was very low calcium carbonate production in the northern Red Sea compared to the south. There is higher calcium carbonate production in the western Pacific than in the east, and along the Central American and northern South American coastline, and this is more pronounced in KAG and LOUGH than ReefHab. In scaling up to the global scale, estimates of $G_{\text {global }}$ based on the models ReefHab (1.40 $\left.\mathrm{Pg} \mathrm{yr}^{-1}\right)$ and SILCCE $\left(1.1 \mathrm{Pg} \mathrm{yr}^{-1}\right)$ were substantially lower than for the other model setups (3.06 $\mathrm{Pg} \mathrm{yr}^{-1}$ for KAG and $4.32 \mathrm{Pg} \mathrm{yr}^{-1}$ for LOUGH).

\subsection{Observed carbonate production rates}

Figure 5 shows the location and magnitude of the calcification observations. Coral core $\left(G_{\text {coral }}\right)$ values are higher $\left(0.5-2.8 \mathrm{~g} \mathrm{~cm}^{-2} \mathrm{yr}^{-1}\right.$; full data set in the Supplement) than $G_{\text {reef }}$ measurements from either census-based (0.1$\left.0.9 \mathrm{~g} \mathrm{~cm}^{-2} \mathrm{yr}^{-1}\right)$ or $\Delta A_{\mathrm{T}}\left(0.003-0.7 \mathrm{~g} \mathrm{~cm}^{-2} \mathrm{yr}^{-1}\right.$; Table 4$)$ methods. In general, coral core data show decreasing $G_{\text {coral }}$ with increasing latitude that is most pronounced in Hawaii and along both east and west Australian coastlines (Fig. 5). 


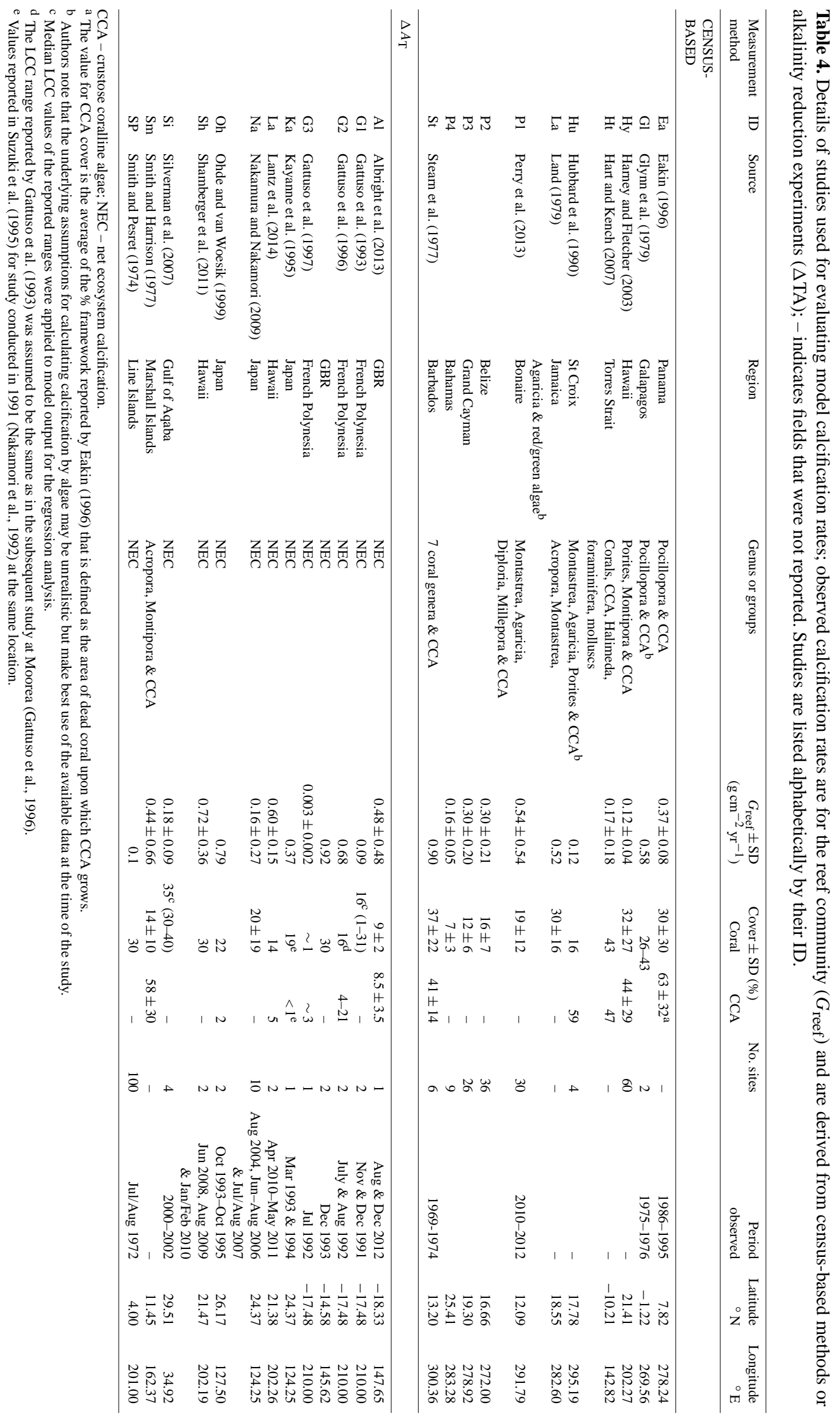


Table 5. Average regional and global reef calcification rates $\left(G_{\text {reef }}\right)$ and global $\mathrm{CaCO}_{3}$ budgets $\left(G_{\text {global }}\right)$ and reef areas derived from the four model setups $(\leq 40 \mathrm{~m})$ and Vecsei (2004). Model $G_{\text {reef }}$ is calculated as the total $\mathrm{CaCO}_{3}$ production multiplied by global average live coral cover (LCC) of $30 \%$ (Hodgson and Liebeler, 2002) and $10 \%$ seabed reefal area with the exception of ReefHab, which uses a function of seabed topographic relief to modify total $\mathrm{CaCO}_{3}$ production to give $G_{\text {reef }}$. Global reef area is $10 \%$ of the total area accounting for inter-reefal area.

\begin{tabular}{lrrrrr}
\hline & \multicolumn{5}{c}{$G_{\text {reef }} \pm \mathrm{SD}\left(\leq 40 \mathrm{~m} ; \mathrm{g} \mathrm{cm}^{-2} \mathrm{yr}^{-1}\right)$} \\
\cline { 2 - 6 } Ocean region & ReefHab & KAG & LOUGH & SILCCE & Vecsei (2004) \\
\hline Caribbean Sea & $0.86 \pm 0.32$ & $0.61 \pm 0.07$ & $0.82 \pm 0.09$ & $0.23 \pm 0.05$ & $0.80 \& 0.01^{\mathrm{a}}$ \\
North Atlantic Ocean & $0.74 \pm 0.40$ & $0.44 \pm 0.22$ & $0.59 \pm 0.21$ & $0.17 \pm 0.10$ & \\
South Atlantic Ocean & $0.51 \pm 0.35$ & $0.40 \pm 0.27$ & $0.57 \pm 0.25$ & $0.16 \pm 0.10$ & \\
Indian Ocean & $0.65 \pm 0.36$ & $0.54 \pm 0.17$ & $0.82 \pm 0.17$ & $0.22 \pm 0.08$ & 0.36 \\
North Pacific Ocean & $0.67 \pm 0.35$ & $0.49 \pm 0.22$ & $0.70 \pm 0.22$ & $0.20 \pm 0.11$ & 0.65 \\
South Pacific Ocean & $0.67 \pm 0.30$ & $0.61 \pm 0.20$ & $0.93 \pm 0.21$ & $0.29 \pm 0.12$ & \\
GBR & $0.66 \pm 0.31$ & $0.67 \pm 0.05$ & $0.76 \pm 0.04$ & $0.25 \pm 0.04$ & 0.45 \\
\hline Global Metrics $(\leq 40 \mathrm{~m})$ & & & & & 1.10 \\
\hline$G_{\text {global }}$ Pg yr & & & & $0.65-0.83$ \\
Reef area $\left(\times 10^{3} \mathrm{~km}^{2}\right)$ & 1.40 & 3.06 & 4.32 & 500 & $303-345$ \\
$G_{\text {reef }} \pm$ SD $\left(\mathrm{g} \mathrm{cm}^{-2} \mathrm{yr}^{-1}\right)$ & $0.65 \pm 0.35$ & $0.51 \pm 0.21$ & $0.72 \pm 0.35$ & $0.21 \pm 0.11$ & $0.09-0.27$ \\
\hline
\end{tabular}

a Values of $G_{\text {reef }}$ for Atlantic/Caribbean framework and biodetrital reef respectively.

However, $G_{\text {coral }}$ is not always smaller at higher latitudes. For example, the Arabian Gulf is toward the upper end of all $G_{\text {coral }}$ observations ( $1.44 \pm 0.57 \mathrm{~g} \mathrm{~cm}^{-2} \mathrm{yr}^{-1}$; full data set in online supplementary material) whereas $G_{\text {coral }}$ in the Gulf of Aqaba is twofold smaller $\left(0.78 \pm 0.28 \mathrm{~g} \mathrm{~cm}^{-1} \mathrm{yr}^{-1}\right)$ despite the similar latitude of the two locations. This result cannot be corroborated by $\Delta A_{\mathrm{T}}$ or census data as there is no observation for the Arabian Gulf, however, there is agreement that calcification in the Gulf of Aqaba is toward to lower end of the observed range for $\Delta A_{\mathrm{T}}$ measured $G_{\text {reef }}$ $\left(0.18 \pm 0.09 \mathrm{~g} \mathrm{~cm}^{-2} \mathrm{yr}^{-1}\right)$ and $G_{\text {coral }}$ measured from coral cores. In contrast, the census-based and $\Delta A_{\mathrm{T}}$ measurements show no latitudinal trends.

\subsection{Model evaluation}

Figure 6 shows the correlation of corresponding model and observed calcification rates. With a slope of 0.97 , the only significant correlation was that between LOUGH and independent coral core data $\left(R^{2}=0.66, p<0.0001\right)$. The $G_{\text {reef }}$ measured by Perry et al. (2013) in the Caribbean also fell close to a $1: 1$ line with LOUGH, but the positive trend was not significant, either when considering just this data subset $\left(R^{2}=0.74, p=0.14, n=4\right)$, or all $\Delta A_{\mathrm{T}}$ measured $G_{\text {reef }}$ $\left(R^{2}=0.57, p=0.14, n=11\right)$. The average regional $G_{\text {reef }}$ estimated by all models showed little geographic difference (Fig. 7), which is in conflict with the conclusions of Vecsei (2004) who found that the Atlantic, including Caribbean reefs, had the highest $G_{\text {reef }}$ of all regions, followed by the Pacific and GBR (Table 5).

The SILCCE model produced a global average $G_{\text {reef }}$ $\left(0.21 \mathrm{~g} \mathrm{~cm}^{-2} \mathrm{yr}^{-1}\right)$ that falls within Vecsei's (2004) esti- mated range $\left(0.09-0.27 \mathrm{~g} \mathrm{~cm}^{-2} \mathrm{yr}^{-1}\right)$ but all other models were in excess of this (Table 5). Similarly, all model estimates of $G_{\text {global }}\left(1.10-4.32 \mathrm{Pg} \mathrm{yr}^{-1}\right.$; Table 5) exceed estimates by Vecsei $\left(2004 ; 0.65-0.83 \mathrm{Pg} \mathrm{yr}^{-1}\right)$. This difference was greatest for KAG and LOUGH (3.06 and $4.32 \mathrm{Pg} \mathrm{yr}^{-1}$ respectively). Global reef area (the area sum of all model cells where $G_{\text {coral }}>0 \mathrm{~g} \mathrm{~cm}^{-2} \mathrm{yr}^{-1}$ and with the $10 \%$ reefal area applied) varies significantly between models (Table 5). ReefHab designates $195 \times 10^{3} \mathrm{~km}^{2}$ as global reef area, which is less than that reported by Vecsei $(2004 ; 304$ $345 \times 10^{3} \mathrm{~km}^{2}$ ); however, the other model setups estimate almost double this $\left(500-592 \times 10^{3} \mathrm{~km}^{2}\right)$.

\section{Discussion}

Four coral reef carbonate production models, contrasting in terms of dependent environmental controls, were evaluated at local, regional and global scales. The results show that only the model using SST alone (LOUGH) is able to predict $G_{\text {coral }}$, and to a degree $G_{\text {reef }}$, with any statistical skill (Fig. 6). At the global scale, there is a large offset between the empirical and model estimates of $G_{\text {global }}$ (Table 5), with the LOUGH $G_{\text {global }}$ estimate approximately a factor of 5 greater than previous estimates by Milliman (1993) and Vecsei (2004). Although $G_{\text {global }}$ values from ReefHab and SILCCE (1.4 and 1.1 $\mathrm{Pg} \mathrm{yr}^{-1}$ ) are significantly closer to the empirical estimates of $G_{\text {global }}$ than the other models, their poor performance at the local reef scale (measured by $G_{\text {reef }}$ and $\left.G_{\text {coral }}\right)$ undermines confidence in their predictive power at $G_{\text {global }}$ scale. Since empirical estimates of $G_{\text {global }}$ cannot themselves be evaluated, it is necessary to examine the fac- 


\section{(a) ReefHab}

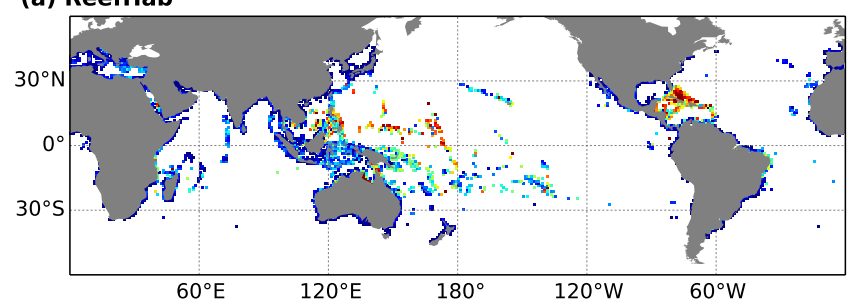

(b) KAG

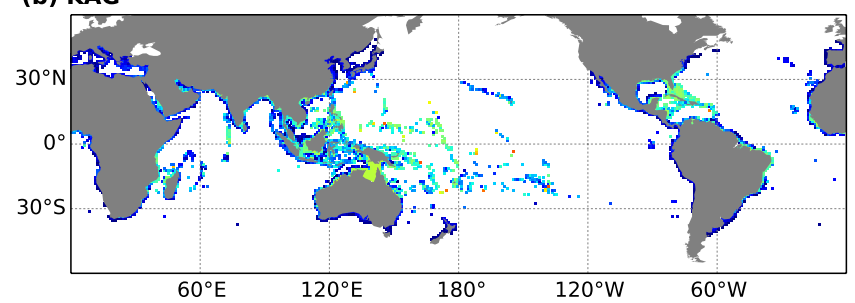

(c) LOUGH

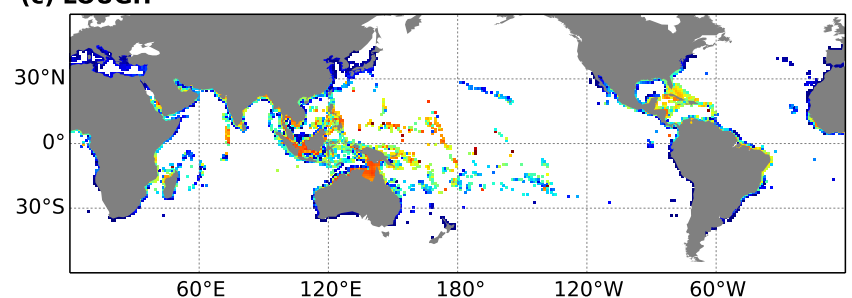

(d) SILCCE

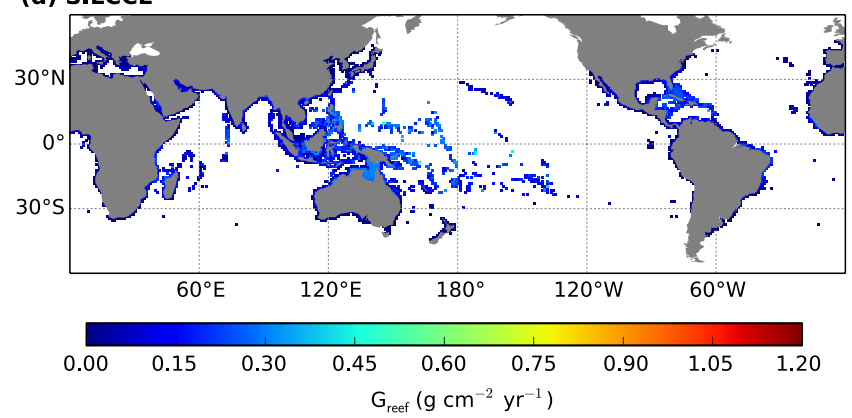

Figure 4. Model outputs of reef carbonate production. Depthintegrated $(\leq 40 \mathrm{~m}) \mathrm{CaCO}_{3}$ production, with $30 \%$ live coral cover (LCC) and $10 \%$ seabed reefal area $\left(G_{\text {reef }}\right)$ for: (a) ReefHab, (b) KAG, (c) LOUGH and (d) SILCCE. The $G_{\text {reef }}$ values displayed are aggregated from the model resolution $\left(0.25^{\circ}\right)$ to a $1^{\circ}$ grid to facilitate visualization.

tors involved in the estimation of $G_{\text {global }}$, and what role they play in terms of the disparity with the various model values.

Global reef area is used in extrapolating $G_{\text {reef }}$ to $G_{\text {global }}$ and so may have a significant effect on both model and empirical estimates of $G_{\text {global }}$. The LOUGH model achieves a global reef area of $567 \times 10^{3} \mathrm{~km}^{2}$, comparable to the reef area used by Milliman (1993) and Opdyke and Walker (1992) of $617 \times 10^{3} \mathrm{~km}^{2}$ taken directly from Smith (1978). Whereas Vecsei (2004) used a revised reef area of $304-345 \times 10^{3} \mathrm{~km}^{2}$ (Spalding and Grenfell, 1997) which is almost half Smith's estimate. Despite this difference in global reef area, Milliman (1993) and Vecsei (2004) estimate comparable values of
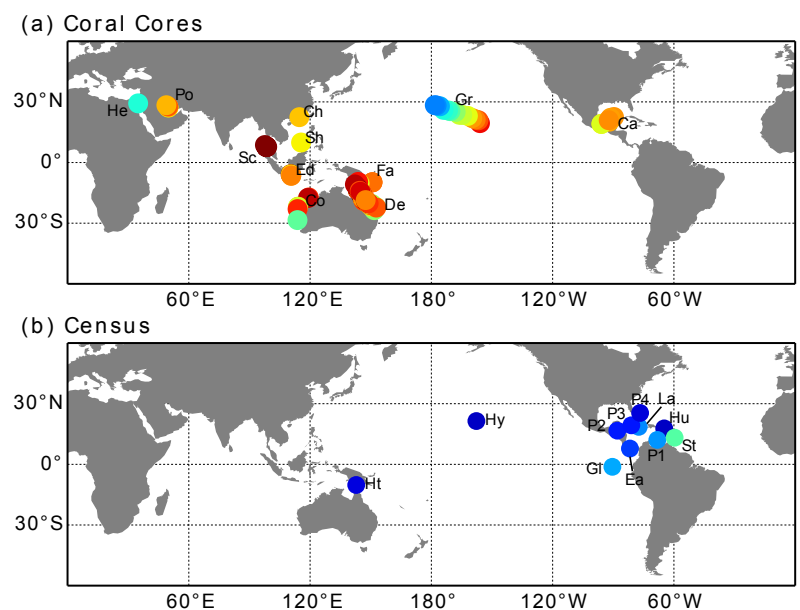

(c) Alkalinity anomaly

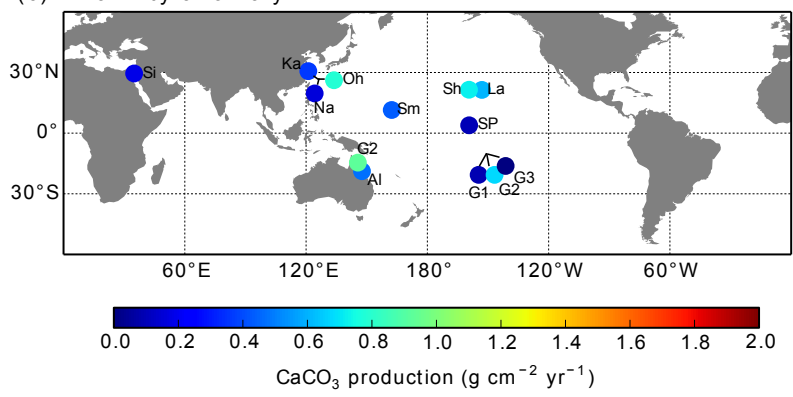

Figure 5. Compilation of published reef carbonate production measurements. Location and magnitude of (a) coral calcification $\left(G_{\text {coral }}\right)$ observed in coral cores and, reef community calcification $\left(G_{\text {reef }}\right)$ measured in (b) census-based and (c) alkalinity anomaly studies (see Tables 4 and 5 for study ID keys).

$G_{\text {global }}$, further confounding evaluation of modelled $G_{\text {global }}$. The question of where to draw the line in terms of establishing reef boundaries is highly pertinent to modelling $G_{\text {global }}$ as it dictates the area considered to be "coral reef". In our analysis, all grid cells with positive $\mathrm{CaCO}_{3}$ production (i.e. $G>0 \mathrm{~g} \mathrm{~cm}^{-2} \mathrm{yr}^{-1}$ ) are considered to contain coral reef, even those that may be close to $0 \mathrm{~g} \mathrm{~cm}^{-2} \mathrm{yr}^{-1}$. Recently formed (immature) reefs with coral communities that have positive $G_{\text {reef }}$ but where little or no $\mathrm{CaCO}_{3}$ framework is present do exist (Spalding et al., 2001) and are accounted for by all four models. However, these coral communities are not included in reef area reported by Spalding and Grenfell (1997) and further information about their production rates and global abundance is needed to accurately quantify their significance in estimating $G_{\text {global }}$ empirically. The presence of these coral communities has been correlated with marginal environmental conditions where low (highly variable) temperatures and high nutrient concentrations are seen (Couce et al., 2012). It logically follows that excluding these marginal reefs by tightening the physicochemical mask for SST to $>20^{\circ} \mathrm{C}$, as derived by Couce et al. (2012), would reduce global reef area and close the gap between empirical and model estimates of $G_{\text {global }}$. Further to this is the assumption within GRAM that 

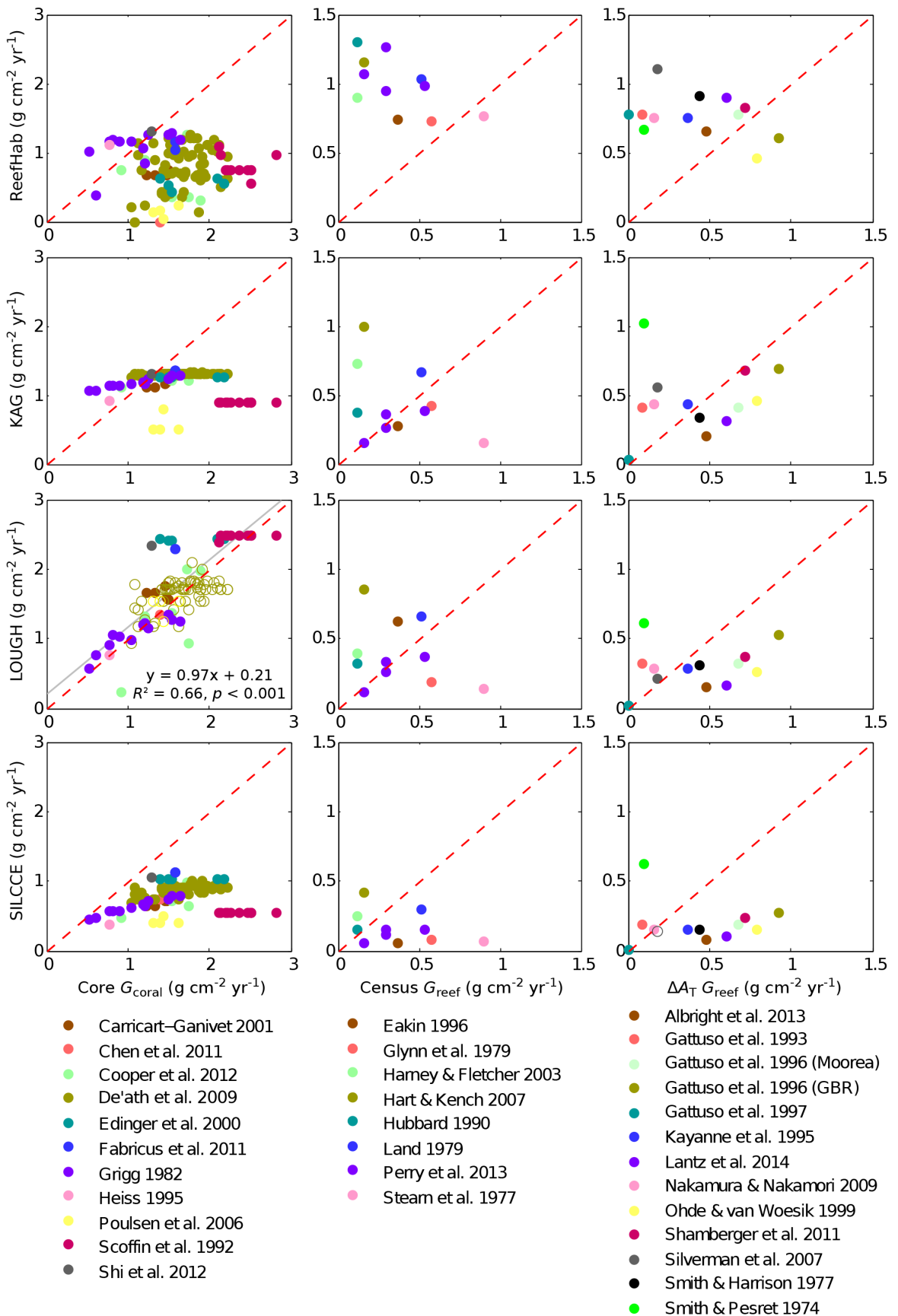

Figure 6. Correlation of observed coral calcification $\left(G_{\text {coral }}\right)$ and reef community calcification $\left(G_{\text {reef }}\right)$ to model predictions for coral core, census-based and alkalinity anomaly $\left(\Delta A_{\mathrm{T}}\right)$ data (1:1 relationship shown as red dashed line). All model estimates are multiplied by the live coral cover (LCC) reported in the observation studies to give $G_{\text {reef }}$, except ReefHab in which $G_{\text {reef }}$ is calculated using a function of topographic relief (TF). The use of TF follows the method of Kleypas (1997); it was derived from empirical observation of reef growth and was a means to scale potential calcification $\left(G_{\text {coral }}\right)$ to produce $G_{\text {reef }}$ in the absence of global data for LCC. All significant linear regressions are plotted $\left(p<0.05\right.$; grey solid line) with equation and regression coefficient $\left(R^{2}\right)$. Data used to develop a model are also plotted (open circles) but were excluded from the regression analysis to preserve data independence. 


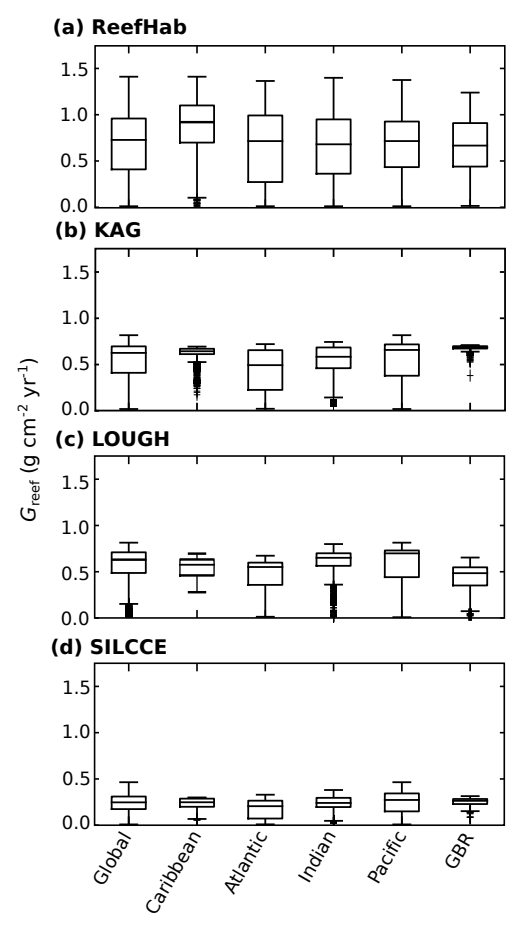

Figure 7. Box and whisker plots of model estimates for global and regional $\mathrm{CaCO}_{3}$ production. A live coral cover (LCC) of $30 \%$ is applied. Range (whiskers), 25th and 75th percentiles (boxes), median (red line), and data outliers (+) are plotted.

the area between reef patches in a "reef" cell (i.e. a cell with $G>0 \mathrm{~g} \mathrm{~cm}^{-2} \mathrm{yr}^{-1}$ ) accounts for $90 \%$ of the cell's area, with only $10 \%$ assumed to be composed of suitable substrate for reef formation and coral recruitment. The availability of suitable substrate has the greatest impact on the biogeography of coral reefs (Montaggioni, 2005) and so clearly needs to be evaluated to improve $G_{\text {global }}$ estimates.

Reef area does not account for all of the disparity between estimates of $G_{\text {global }}$; attenuation of $G_{\text {reef }}$ with depth may also be a causal factor. In both Atlantic and Indo-Pacific reefs, there was an exponential trend, decreasing with depth $(\leq 60 \mathrm{~m})$, in $G_{\text {reef }}$ data collated by Vecsei (2001). Modelled $G_{\text {reef }}$ estimates should, therefore, also vary as a function of depth. In its published form, LOUGH produces the same value for $G_{\text {reef }}$ throughout the water column; however, we can account for this model limitation by imposing a lightsensitive correction in the form of an exponential function to the output from LOUGH so that $G_{\text {reef }}$ is a function of surface $\left(G_{\text {surf }}\right)$ and depth $(z)$ :

$G_{\text {reef }}=G_{\text {surf }} \cdot e^{-k_{g} z}$

where $k_{g}$ is a constant controlling the degree of light attenuation with depth, in this estimate $K_{490}$ was used. Eq. (19) has the same form as that for calculating light availability (Eq. 3) used in both ReefHab and KAG. Following this adjustment, the LOUGH $G_{\text {global }}$ estimate is reduced to
2.56 $\mathrm{Pg} \mathrm{yr}^{-1}$, which is closer to empirical estimates. However, where light availability has been incorporated into other models no significant skill in predicting $G_{\text {coral }}$ or $G_{\text {reef }}$ was observed (ReefHab and KAG in Fig. 6).

A further factor that strongly affects $G_{\text {reef }}$ and $G_{\text {global }}$ estimates is the percentage of the reef covered by calcifying organisms (generally abridged as the term "live coral cover", or LCC, although implicitly including other calcifiers). Applying the global average LCC of $30 \%$ clearly does not account for the large spatial and temporal variation in coral cover $(<1-43 \%$ in the data set collated here; Table 4$)$. Indeed, only a very limited number of Pacific islands (4/46) were found to have $\geq 30 \%$ LCC between 2000 and 2009 in the compilation of Vroom (2011). The global average of $30 \%$ was calculated from surveys of 1107 reefs between 1997 and 2001 (Hodgson and Liebeler, 2002) and represents total hard coral cover (LCC plus recently killed coral), so is an overestimate of LCC. LOUGH has significant skill in replicating observed $G_{\text {coral }}$ and has some skill in predicting $G_{\text {reef values observed }}$ by a standardized census method (ReefBudget; Perry et al., 2012), but only when the local observed LCC is applied. If however, the global average LCC is applied to LOUGH the correlation with $G_{\text {reef }}$ is lost. In addition, the global average coral cover may also account for the uniformity of regional $G_{\text {reef }}$ values (Fig. 7), in contrast to the significant differences between regions identified by Vecsei (2004) - for example, the Atlantic reefs (including the Caribbean) having the greatest $G_{\text {reef }}\left(0.8 \mathrm{~g} \mathrm{~cm}^{-2} \mathrm{yr}^{-1}\right)$ and reefs in the Indian Ocean the smallest $G_{\text {reef }}\left(0.36 \mathrm{~g} \mathrm{~cm}^{-2} \mathrm{yr}^{-1}\right.$; Vecsei, 2004; Table 5). The pattern is reversed in terms of coral cover, with Indo-Pacific reefs having $\sim 35 \%$ hard coral cover compared to $\sim 23 \%$ on Atlantic reefs (Hodgson and Liebeler, 2002). Further studies have shown that Caribbean reefs have greater $G_{\text {reef }}$ and vertical accumulation rates than Indo-Pacific reefs, possibly due to increased competition for space on the latter (Perry et al., 2008). These issues highlight the need for coral cover to vary dynamically within models, allowing it to change spatially and temporally according to coral population demographics (mortality, growth and recruitment).

A specific example of unrealistic $G_{\text {reef }}$ is seen for the Gulf of Carpentaria, where there are no known currently accreting reefs (Harris et al., 2004) but projections of carbonate production according to output from the LOUGH model are particularly high (Fig. 4). At least seven submerged reefs have been discovered in the Gulf of Carpentaria and a further 50 may exist, but these reefs ceased growth $\sim 7 \mathrm{kyr}$ BP when they were unable to keep up with sea level rise (Harris et al., 2008). Failure to repopulate may be due to a combination of factors including very low larval connectivity in the Gulf of Carpentaria (Wood et al., 2014) and high turbidity, due to re-suspension of bottom sediments and particulate input from rivers (Harris et al., 2008). ReefHab is the only model to predict an absence of reef accretion in the majority of the Gulf of Carpentaria (Fig. 4), indicating that model sensitivity to light attenuation is essential. This example also raises 
two further points: firstly, that there are certainly undiscovered reefs that are not accounted for in empirical estimates of $G_{\text {global }}$ and, secondly, that larval connectivity should be considered in simulations of $G_{\text {reef }}$ because of its role in regulating coral abundance after disturbance (Almany et al., 2009; Jones et al., 2009).

In addition to static coral cover, growth parameters $G_{\text {max }}$, Eq. (2); $E_{\mathrm{k}}$, Eq. (2) and (6); $k_{\text {day }}$, Eq. (7); $k_{\text {dark }}$, Eq. (8); $k_{r^{\prime}}$ and $k_{p^{\prime}}$ Eq. (18) - did not vary geographically, having the same value in all model grid cells. This potentially affected the skill of KAG in reproducing $G_{\text {coral }}$ and $G_{\text {reef }}$ since in the original application of the model (Kleypas et al., 2011) parameters $\left(k_{\mathrm{day}}, k_{\mathrm{dark}}\right.$ and $\left.E_{\mathrm{k}}\right)$ were determined for observations at the location of the reef transect that was simulated. However, when looking at the correlation of model to data it is important to acknowledge the observational variability and error. The standard deviation, where reported, for census-based and $\Delta A_{\mathrm{T}}$ measured $G_{\text {reef }}$ is $\leq 100 \%$ of the mean (Table 4). In addition to this variability, observational error is greater in census-based measurements of $G_{\text {reef }}$ than $\Delta A_{\mathrm{T}}$ measurements (Vecsei, 2004). In a review of reef metabolism, $G_{\text {reef }}$ was shown to vary considerably (0.05$1.26 \mathrm{~g} \mathrm{~cm}^{-2} \mathrm{yr}^{-1}$ ) depending on the abundance of coral and coralline algae (Gattuso et al., 1998). $G_{\text {reef }}$ (measured by $\Delta A_{\mathrm{T}}$ ) appears to vary little across Pacific coral reefs (Smith and Kinsey, 1976) but Gattuso et al. (1998) attribute this to the similarity of these reefs in terms of community structure and composition, as well as coral cover. The apparent agreement between LOUGH and Caribbean $G_{\text {reef }}$ (as reported by Perry et al., 2013) suggests that a standardized experimental methodology for measuring $G_{\text {reef }}$ is needed and implementing this would also provide a consistent data set that would be invaluable for model evaluation. Unexpectedly, this result also suggests that LOUGH may have skill in predicting $G_{\text {reef }}$ in the Atlantic Ocean despite the absence of massive Porites sp. on which the LOUGH model is built. Porites is a particularly resilient genus (e.g. Barnes et al., 1970; Coles and Jokiel, 1992; Loya et al., 2001; Hendy et al., 2003; Fabricius et al., 2011) and so applicability to other reef settings, coral genera and calcifiers as a whole is surprising. $G_{\text {coral }}$ of a single species has been used in some census-based studies to calculate the $G_{\text {coral }}$ of all scleractinian corals present (Bates et al., 2010) and the LOUGH results suggest this generalization may be appropriate.

Unlike census-based and $\Delta A_{\mathrm{T}}$ methodologies, $G_{\text {coral }}$ measured from coral cores spans multiple centuries (Lough and Barnes, 2000) and so smoothes the stochastic nature of coral growth and variations in reef accretion. $G_{\text {coral }}$ and $G_{\text {reef }}$ do vary a great deal temporally. For example, diurnal fluctuations may be up to fivefold and result in net dissolution at night (e.g. Barnes, 1970; Chalker, 1976; Barnes and Crossland, 1980; Gladfelter, 1984; Constantz, 1986; McMahon et al., 2013). The median ratio of light to dark calcification rates is 3.0; however, measurements of dissolution in individual corals are rarely reported (Gattuso et al., 1999). At in- termediate timescales (weekly-monthly) $G_{\text {coral }}$ may vary by a factor of 3, with a degree of seasonal chronology (Crossland, 1984; Dar and Mohammed, 2009; Albright et al., 2013). Over longer timescales ( $\geq 1 \mathrm{yr}$ ), $G_{\text {coral }}$ is less variable (Buddemeier and Kinzie, 1976) and both Hatcher (1997) and Perry et al. (2008) describe reef processes hierarchically according to temporal and spatial scales, finding that time spans of a year or more are required to study processes of reef accretion. The numerous observations of $G_{\text {coral }}$ measured from coral cores is a further advantage over the sparse census and $\Delta A_{\mathrm{T}}$ determinations of $G_{\text {reef }}$ which are generally more costly and labour-intensive. More observations of $G_{\text {reef }}$ are, however, essential to improve statistical power and evaluation of model outputs. $G_{\text {reef }}$ is also invaluable from a monitoring perspective (reviewed by Baker et al., 2008; e.g. Ateweberhan and McClanahan, 2010) by providing an effective measure of reef health that encompasses the whole reef community and accounting for different relative compositions of corals and algae (Vroom, 2011; Bruno et al., 2014). These benefits provide impetus for future measurements of $G_{\text {reef }}$, but our results demonstrate that a standardization of the methodology (as demonstrated in Perry et al., 2013) must be applied.

The four models used in this study all simplify the physiological mechanisms of calcification to predict $G_{\text {coral }}$ and $G_{\text {reef }}$ as a function of one or two external environmental variables. Calcification is principally a biologically controlled process in corals (e.g. Puverel et al., 2005); occurring at the interface between the polyp's aboral layer and the skeleton, which is separated from seawater by the coelenteron and oral layer (Gattuso et al., 1999). This compartmentalization means that the reagents for calcification $\mathrm{Ca}^{2+}$ and inorganic carbon species) must be transported from the seawater through the tissue of the coral polyp to the site of calcification (reviewed in Allemand et al., 2011). Active transport of $\mathrm{Ca}^{2+}$ bicarbonate ions $\left(\mathrm{HCO}_{3}^{-}\right)$to the site of calcification and removal of protons $\left(\mathrm{H}^{+}\right)$regulates the $\mathrm{pH}$ and $\Omega_{\mathrm{a}}$ of the calcifying fluid (found between aboral ectoderm and skeleton) and requires energy (reviewed in Tambutté et al., 2011). Although the precise mechanism is unknown it is thought that in light zooxanthellate corals derive this energy from the photosynthetic products (principally oxygen and glycerol) of their symbionts, which is thought to partially explain the phenomenon of light-enhanced calcification (reviewed in Gattuso et al., 1999; Allemand et al., 2011; Tambutté et al., 2011). Both the ReefHab and KAG models use this relationship with light to determine $G_{\text {coral. }}$. However, corals that have lost their symbionts by "bleaching" continue to show enhanced calcification in the light (Colombo-Pallotta et al., 2010). As such, irradiance alone cannot account for changes in $G_{\text {coral }}$. Precipitation of aragonite from the calcifying fluid has been assumed to follow the same reaction kinetics as inorganic calcification with respect to $\Omega_{\mathrm{a}}$ (Hohn and Merico, 2012), i.e. $k_{p} \cdot\left(\Omega_{a}-1\right)^{n}$ (following Burton and Walter, 1987). KAG and SILCCE both use this function of 
seawater $\Omega_{\mathrm{a}}$ in calculating calcification; however, despite the logical connection between $\Omega_{\mathrm{a}}$ and $G_{\text {coral }}$ neither model could reproduce observed $G_{\text {coral }}$ values. Inorganic precipitation of aragonite increases linearly with temperature (Burton and Walter, 1987) as does respiration in corals when oxygen is not limited (Colombo-Pallotta et al., 2010). This temperature dependence may explain the strong correlation found by Lough (2008) between Porites growth and SST and the skill LOUGH has shown in this study at reproducing $G_{\text {coral }}$ observed values.

This study has shown that it is possible to predict global variations in coral carbonate production rates $\left(G_{\text {coral }}\right)$ across an environmental gradient with significant skill simply as a function SST (LOUGH). However, the LOUGH model assumes a linear relationship between SST and coral calcification $\left(G_{\text {coral }}\right)$ whereas the increase in calcification as a function of increased temperature obviously stops at a certain threshold. For example, there is substantive evidence of declining coral calcification rates in recent decades coinciding with increasing temperatures (e.g. Cooper et al., 2008; De'ath et al., 2009, 2013; Cantin et al., 2010; Manzello, 2010; Tanzil et al., 2013). Further laboratory experiments have found a Gaussian or bell-shaped response to increasing temperature with optima between 25 and $27^{\circ} \mathrm{C}$ (e.g. Clausen and Roth, 1975; Jokiel and Coles, 1977; Reynaud-Vaganay et al., 1999; Marshall and Clode, 2004). In contrast to the linear SST relationship in LOUGH, Silverman et al. (2009; SILCCE) use the Gaussian relationship found by Marshall and Clode (2004) to modulate the rate of calcification derived from inorganic calcification $\left(G_{\mathrm{i}}\right)$ calculated from $\Omega_{\mathrm{a}}$. But, the output from SILCCE is shown to be a poor predictor of $G_{\text {coral }}$ or $G_{\text {reef }}$ in this study. While using the LOUGH model alone is clearly not appropriate when applied to future temperature simulations, environmental gradients in $G_{\text {coral }}$ established using LOUGH could be modulated to account for the physiological effect for heat-stress using degree-heatingmonths (e.g. Donner et al., 2005; McClanahan et al., 2007) or summer SST anomaly (e.g. McWilliams et al., 2005). This approach would then account for the evidence that corals exhibit widely differing temperature optima depending on their temperature history or climatological-average temperature (Clausen and Roth, 1975).

Since none of the models evaluated in this study showed significant skill in capturing global patterns of $G_{\text {reef }}$, none of the models provide a reliable estimate of $G_{\text {global }}$. Successful up-scaling of carbonate production to the reef $\left(G_{\text {reef }}\right)$ and global domain $\left(G_{\text {global }}\right)$ will require accounting for both depth attenuation (e.g. light sensitivity) and inclusion of population demographics affecting calcifier abundance. An ecosystem modelling approach that captures demographic processes such as mortality and recruitment, together with growth, would result in a dynamically and spatially varying estimate of live coral cover. It is also clear that a standardized methodology for census-based measurements is required, as evident from the improved model-data fit in a subset of data collected using the ReefBudget methodology (Perry et al., 2012). Coral calcification rates have slowed by an estimated $30 \%$ in the last three decades (e.g. Bruno and Selig, 2007; Cantin et al., 2010; De'ath et al., 2013; Tanzil et al., 2013) reinforcing the pessimistic prognosis for reefs into the future under climate change (e.g. Hoegh-Guldberg et al., 2007; Couce et al., 2013; Frieler et al., 2013); numerical modelling is an essential tool for validating and quantifying the severity of these trends.

\section{The Supplement related to this article is available online at doi:10.5194/bg-12-1339-2015-supplement.}

Acknowledgements. This work was supported by an AXA Research Fund Doctoral Fellowship to N. S. Jones, a Royal Society Advanced Fellowship and UK Ocean Acidification Research Program grant (NE/H017453/1) to A. Ridgwell, and a RCUK Academic Fellowship to E. J. Hendy. We would also like to thank Fiona Whitaker, Pru Foster, Sally Wood and Elena Couce for stimulating ideas and discussions and Jean-Pierre Gattuso (Editor) and reviewers (Bradley Opdyke and one anonymous) for their insightful comments.

Edited by: J.-P. Gattuso

\section{References}

Australian Institute of Marine Science (AIMS): Coral calcification in massive Porites of the Great Barrier Reef, over a 400 year period, available at: http://data.aims.gov.au/metadataviewer/uuid/ ff433c10-ea4d-11dc-823c-00008a07204e (last access: 30 January 2014), 2014a.

Australian Institute of Marine Science (AIMS): Growth of Western Australian corals in the Anthropocene, available at: http://data.aims.gov.au/metadataviewer/uuid/ 4f39c641-8450-4ea0-b2b6-4f3d582645f8 (last access: 14 Febuary 2014), 2014b.

Albright, R., Langdon, C., and Anthony, K. R. N.: Dynamics of seawater carbonate chemistry, production, and calcification of a coral reef flat, central Great Barrier Reef, Biogeosciences, 10, 6747-6758, doi:10.5194/bg-10-6747-2013, 2013.

Allemand, D., Tambutté, É., Zoccola, D., and Tambutte, S.: Coral calcification, cells to reefs, in: Coral reefs: an ecosystem in transition, edited by: Dubinsky, Z. and Stambler, N., Springer, Dordrecht, Netherlands, 119-150, 2011.

Almany, G. R., Connolly, S. R., Heath, D. D., Hogan, J. D., Jones, G. P., McCook, L. J., Mills, M., Pressey, R. L., and Williamson, D. H.: Connectivity, biodiversity conservation and the design of marine reserve networks for coral reefs, Coral Reefs, 28, 339351, 2009.

Andersson, A. J. and Gledhill, D.: Ocean acidification and coral reefs: effects on breakdown, dissolution, and net ecosystem calcification, Annu. Rev. Mar. Sci., 5, 321-348, 2013. 
Anthony, K. R. N., Kline, D. I., Diaz-Pulido, G., Dove, S., and Hoegh-Guldberg, O.: Ocean acidification causes bleaching and productivity loss in coral reef builders, P. Natl. Acad. Sci. USA, 105, 17442-17446, 2008.

Anthony, K. R. N., Kleypas, J. A., and Gattuso, J.-P.: Coral reefs modify their seawater carbon chemistry - implications for impacts of ocean acidification, Glob. Change Biol., 17, 3655-3666, 2011.

Antonov, J. I., Seidov, D., Boyer, T. P., Locarnini, R. A., Mishonov, A. V., Garcia, H. E., Baranova, O. K., Zweng, M. M., and Johnson, D. R.: World Ocean Atlas 2009, volume 2: salinity, in: NOAA Atlas NESDIS 69, edited by: Levitus, S., U.S. Government Printing Office, Washington, D.C., 1-184, 2010.

Ateweberhan, M. and McClanahan, T. R.: Relationship between historical sea-surface temperature variability and climate change-induced coral mortality in the western Indian Ocean, Mar. Pollut. Bull., 60, 964-970, 2010.

Baker, A. C., Glynn, P. W., and Riegl, B.: Climate change and coral reef bleaching: an ecological assessment of long-term impacts, recovery trends and future outlook, Estuar. Coast. Shelf S., 80, 435-471, 2008.

Barnes, D. J.: Coral skeletons - an explanation of their growth and structure, Science, 170, 1305-1308, 1970.

Barnes, D. J. and Chalker, B. E.: Calcification and photosynthesis in reef-building corals and algae, in: Ecosystems of the World, 25: coral reefs, edited by: Dubinsky, Z., Elsevier Science Publishing Company, Amsterdam, The Netherlands, 109-131, 1990.

Barnes, D. J. and Crossland, C. J.: Diurnal and seasonal variation in the growth of staghorn coral measured by time-lapse photography, Limnol. Oceanogr., 25, 1113-1117, 1980.

Barnes, D. S., Brauer, R. W., and Jordan, M. R.: Locomotory response of Acanthaster planci to various species of coral, Nature, 228, 342-344, 1970.

Bates, N. R., Amat, A., and Andersson, A. J.: Feedbacks and responses of coral calcification on the Bermuda reef system to seasonal changes in biological processes and ocean acidification, Biogeosciences, 7, 2509-2530, doi:10.5194/bg-7-25092010, 2010.

Bishop, J. K. B. and Rossow, W. B.: Spatial and temporal variability of global surface solar irradiance, J. Geophys. Res.-Oceans, 96, 16839-16858, 1991.

Bishop, J. K. B., Rossow, W. B., and Dutton, E. G.: Surface solar irradiance from the International Satellite Cloud Climatology Project 1983-1991, J. Geophys. Res.-Atmos., 102, 6883-6910, 1997.

Boucher, G., Clavier, J., Hily, C., and Gattuso, J.-P.: Contribution of soft-bottoms to the community metabolism (primary production and calcification) of a barrier reef flat (Moorea, French Polynesia), J. Exp. Mar. Biol. Ecol., 225, 269-283, 1998.

Bruno, J. and Selig, E.: Regional decline of coral cover in the IndoPacific: timing, extent, and subregional comparisons, PloS one, 2, e711, doi:10.1371/journal.pone.0000711, 2007.

Bruno, J. F., Precht, W. F., Vroom, P. S., and Aronson, R. B.: Coral reef baselines: how much macroalgae is natural?, Mar. Pollut. Bull., 80, 24-29, 2014.

Buddemeier, R. W. and Kinzie, R. A.: Coral growth, Oceanogr. Mar. Biol. Ann. Rev., 14, 183-225, 1976.
Burton, E. A. and Walter, L. M.: Relative precipitation rates of aragonite and $\mathrm{Mg}$ calcite from seawater: temperature or carbonate ion control?, Geology, 15, 111-114, 1987.

Cantin, N. E., Cohen, A. L., Karnauskas, K. B., Tarrant, A. M., and McCorkle, D. C.: Ocean warming slows coral growth in the central Red Sea, Science, 329, 322-325, 2010.

Carricart-Ganivet, J. P. and Merino, M.: Growth responses of the reef-building coral Montastraea annularis along a gradient of continental influence in the southern Gulf of Mexico, Bull. Mar. Sci., 68, 133-146, 2001.

Chalker, B. E.: Calcium-transport during skeletogenesis in hermatypic corals, Comp. Biochem. Phys. A, 54, 455-459, 1976.

Chalker, B. E.: Simulating light-saturation curves for photosynthesis and calcification by reef-building corals, Mar. Biol., 63, 135$141,1981$.

Chave, K. E., Smith, S. V., and Roy, K. J.: Carbonate production by coral reefs, Mar. Geol., 12, 123-140, 1972.

Chen, T., Yu, K., Shi, Q., Chen, T., and Wang, R.: Effect of global warming and thermal effluents on calcification of the Porites coral in Daya Bay, northern South China Sea, J. Trop. Oceanogr., 30, 1-9, 2011.

Clausen, C. D. and Roth, A. A.: Effect of temperature and temperature adaptation on calcification rate in the hermatypic coral Pocillopora damicornis, Mar. Biol., 33, 93-100, 1975.

Coles, S. L. and Jokiel, P. L.: Effects of salinity on coral reefs, in: Pollution in tropical aquatic systems, edited by: Connell, D. W. and Hawker, D. W., CRC Press, London, 147-166, 1992.

Colombo-Pallotta, M. F., Rodriguez-Roman, A., and IglesiasPrieto, R.: Calcification in bleached and unbleached Montastraea faveolata: evaluating the role of oxygen and glycerol, Coral Reefs, 29, 899-907, 2010.

Constantz, B. R.: Coral skeleton construction a physiochemically dominated process, Palaios, 1, 152-157, 1986.

Cooper, T. F., De'ath, G., Fabricius, K. E., and Lough, J. M.: Declining coral calcification in massive Porites in two nearshore regions of the northern Great Barrier Reef, Glob. Change Biol., 14, 529-538, 2008.

Cooper, T. F., O'Leary, R. A., and Lough, J. M.: Growth of Western Australian corals in the Anthropocene, Science, 335, 593-596, 2012.

Couce, E., Ridgwell, A., and Hendy, E. J.: Environmental controls on the global distribution of shallow-water coral reefs, J. Biogeogr., 39, 1508-1523, 2012.

Couce, E., Ridgwell, A., and Hendy, E. J.: Future habitat suitability for coral reef ecosystems under global warming and ocean acidification, Glob. Change Biol., 19, 3592-3606, 2013.

Crossland, C. J.: Seasonal-variations in the rates of calcification and productivity in the coral Acropora formosa on a high-latitude reef, Mar. Ecol. Prog. Ser., 15, 135-140, 1984.

Dar, M. A. and Mohammed, T. A.: Seasonal variations in the skeletogensis process in some branching corals in the Red Sea, Thalassas, 25, 31-44, 2009.

De'ath, G., Lough, J. M., and Fabricius, K. E.: Declining coral calcification on the Great Barrier Reef, Science, 323, 116-119, 2009.

De'ath, G., Fabricius, K., and Lough, J.: Yes - coral calcification rates have decreased in the last twenty-five years!, Mar. Geol., 346, 400-402, 2013.

Donner, S. D., Skirving, W. J., Little, C. M., Oppenheimer, M., and Hoegh-Guldberg, O.: Global assessment of coral bleaching and 
required rates of adaptation under climate change, Glob. Change Biol., 11, 2251-2265, 2005.

Eakin, C. M.: Where have all the carbonates gone?, A model comparison of calcium carbonate budgets before and after the 19821983 El Niño at Uva Island in the eastern Pacific, Coral Reefs, 15, 109-119, 1996.

Edinger, E. N., Limmon, G. V., Jompa, J., Widjatmoko, W., Heikoop, J. M., and Risk, M. J.: Normal coral growth rates on dying reefs: are coral growth rates good indicators of reef health?, Mar. Pollut. Bull., 40, 404-425, 2000.

Erez, J., Reynaud, S., Silverman, J., Schneider, K., and Allemand, D.: Coral calcification under ocean acidification and global change, in: Coral reefs: an ecosystem in transition, edited by: Dubinsky, Z. and Stambler, N., Springer, Dordrecht, Netherlands, 151-176, 2011

Fabricius, K. E., Langdon, C., Uthicke, S., Humphrey, C., Noonan, S., De'ath, G., Okazaki, R., Muehllehner, N., Glas, M. S., and Lough, J. M.: Losers and winners in coral reefs acclimatized to elevated carbon dioxide concentrations, Nat. Clim. Change, 1, 165-169, 2011.

Frieler, K., Meinshausen, M., Golly, A., Mengel, M., Lebek, K., Donner, S. D., and Hoegh-Guldberg, O.: Limiting global warming to $2{ }^{\circ} \mathrm{C}$ is unlikely to save most coral reefs, Nat. Clim. Change, 3, 165-170, 2013.

Gattuso, J.-P., Pichon, M., Delesalle, B., and Frankignoulle, M.: Community metabolism and air-sea $\mathrm{CO}_{2}$ fluxes in a coral-reef ecosystem (Moorea, French Polynesia), Mar. Ecol. Prog. Ser., 96, 259-267, 1993.

Gattuso, J.-P., Pichon, M., Delesalle, B., Canon, C., and Frankignoulle, M.: Carbon fluxes in coral reefs. I. Lagrangian measurement of community metabolism and resulting air-sea $\mathrm{CO}_{2}$ disequilibrium, Mar. Ecol. Prog. Ser., 145, 109-121, 1996.

Gattuso, J.-P., Payri, C. E., Pichon, M., Delesalle, B., and Frankignoulle, M.: Primary production, calcification, and airsea $\mathrm{CO}_{2}$ fluxes of a macroalgal-dominated coral reef community (Moorea, French Polynesia), J. Phycol., 33, 729-738, 1997.

Gattuso, J.-P., Frankignoulle, M., and Wollast, R.: Carbon and carbonate metabolism in coastal aquatic ecosystems, Annu. Rev. Ecol. Syst., 29, 405-434, 1998.

Gattuso, J.-P., Allemand, D., and Frankignoulle, M.: Photosynthesis and calcification at cellular, organismal and community levels in coral reefs: a review on interactions and control by carbonate chemistry, Am. Zool., 39, 160-183, 1999.

Gladfelter, E. H.: Skeletal development in Acropora cervicornis: 3. a comparison of monthly rates of linear extension and calciumcarbonate accretion measured over a year, Coral Reefs, 3, 51-57, 1984.

Glynn, P. W., Wellington, G. M., and Birkeland, C.: Coral reef growth in the Galapagos: limitation by sea urchins, Science, 203, 47-49, 1979.

Grigg, R. W.: Darwin Point: a threshold for atoll formation, Coral Reefs, 1, 29-34, 1982.

Harney, J. N. and Fletcher, C. H.: A budget of carbonate framework and sediment production, Kailua Bay, Oahu, Hawaii, J. Sediment. Res., 73, 856-868, 2003.

Harris, P. T., Heap, A. D., Wassenberg, T., and Passlow, V.: Submerged coral reefs in the Gulf of Carpentaria, Australia, Mar. Geol., 207, 185-191, 2004.
Harris, P. T., Heap, A. D., Marshall, J. F., and McCulloch, M.: A new coral reef province in the Gulf of Carpentaria, Australia: colonisation, growth and submergence during the early Holocene, Mar. Geol., 251, 85-97, 2008.

Hart, D. E. and Kench, P. S.: Carbonate production of an emergent reef platform, Warraber Island, Torres Strait, Australia, Coral Reefs, 26, 53-68, 2007.

Hatcher, B. G.: Coral reef ecosystems: how much greater is the whole than the sum of the parts?, Coral Reefs, 16, S77-S91, 1997.

Haxeltine, A. and Prentice, I. C.: BIOME3: an equilibrium terrestrial biosphere model based on ecophysiological constraints, resource availability, and competition among plant functional types, Global Biogeochem. Cy., 10, 693-709, 1996.

Heiss, G. A.: Carbonate production by scleractinian corals at Aqaba, Gulf of Aqaba, Red Sea, Facies, 33, 19-34, 1995.

Hendy, E. J., Lough, J. M., and Gagan, M. K.: Historical mortality in massive Porites from the central Great Barrier Reef, Australia: evidence for past environmental stress?, Coral Reefs, 22, 207 215, 2003.

Hodgson, G. and Liebeler, J.: The global coral reef crisis: trends and solutions 1997-2001, Reef Check, California, USA, available at: http://reefcheck.org/about_RC_Reef/publications/ ReefCheckReport.pdf/ReefCheck5YearReport.pdf (last access: 23 February 2015), 2002.

Hoegh-Guldberg, O.: Coral reef ecosystems and anthropogenic climate change, Reg. Environ. Change, 11, S215-S227, 2011.

Hoegh-Guldberg, O., Mumby, P. J., Hooten, A. J., Steneck, R. S., Greenfield, P., Gomez, E., Harvell, C. D., Sale, P. F., Edwards, A. J., Caldeira, K., Knowlton, N., Eakin, C. M., Iglesias-Prieto, R., Muthiga, N., Bradbury, R. H., Dubi, A., and Hatziolos, M. E.: Coral reefs under rapid climate change and ocean acidification, Science, 318, 1737-1742, 2007.

Hohn, S. and Merico, A.: Modelling coral polyp calcification in relation to ocean acidification, Biogeosciences, 9, 4441-4454, 2012, http://www.biogeosciences.net/9/4441/2012/.

Hubbard, D. K., Miller, A. I., and Scaturo, D.: Production and cycling of calcium carbonate in a shelf-edge reef system (St Croix, United States Virgin Islands): applications to the nature of reef systems in the fossil record, J. Sediment. Petrol., 60, 335-360, 1990.

Johnson, M. D. and Carpenter, R. C.: Ocean acidification and warming decrease calcification in the crustose coralline alga $H y$ drolithon onkodes and increase susceptibility to grazing, J. Exp. Mar. Biol. Ecol., 434, 94-101, 2012.

Johnson, M. D., Moriarty, V. W., and Carpenter, R. C.: Acclimatization of the crustose coralline alga Porolithon onkodes to variable $\mathrm{pCO}_{2}$, Plos One, 9, e87678, doi:10.1371/journal.pone.0087678, 2014.

Jokiel, P. L. and Coles, S. L.: Effects of temperature on the mortality and growth of Hawaiian reef corals, Mar. Biol., 43, 201-208, 1977.

Jones, G. P., Almany, G. R., Russ, G. R., Sale, P. F., Steneck, R. S., van Oppen, M. J. H., and Willis, B. L.: Larval retention and connectivity among populations of corals and reef fishes: history, advances and challenges, Coral Reefs, 28, 307-325, 2009. 
Kayanne, H., Suzuki, A., and Saito, H.: Diurnal changes in the partial pressure of carbon dioxide in coral reef water, Science, 269, 214-216, 1995.

Kleypas, J. A.: Modeled estimates of global reef habitat and carbonate production since the last glacial maximum, Paleoceanography, 12, 533-545, 1997.

Kleypas, J. A. and Langdon, C.: Coral reefs and changing seawater carbonate chemistry. In: Coral reefs and climate change: science and management, AGU, Washington, DC, 73-110, 2006.

Kleypas, J. A. and Yates, K. K.: Coral reefs and ocean acidification, Oceanography, 22, 108-117, 2009.

Kleypas, J. A., Buddemeier, R. W., Archer, D., Gattuso, J.-P., Langdon, C., and Opdyke, B. N.: Geochemical consequences of increased atmospheric carbon dioxide on coral reefs, Science, 284, 118-120, 1999.

Kleypas, J. A., Buddemeier, R. W., Eakin, C. M., Gattuso, J.P., Guinotte, J., Hoegh-Guldberg, O., Iglesias-Prieto, R., Jokiel, P. L., Langdon, C., Skirving, W., and Strong, A. E.: Comment on "Coral reef calcification and climate change: the effect of ocean warming”, Geophys. Res. Lett., 32, L08601, doi:10.1029/2004g1022329, 2005.

Kleypas, J. A., Anthony, K. R. N., and Gattuso, J.-P.: Coral reefs modify their seawater carbon chemistry - case study from a barrier reef (Moorea, French Polynesia), Glob. Change Biol., 17, 3667-3678, 2011.

Knutson, D. W., Smith, S. V., and Buddemeier, R. W.: Coral chronometers: seasonal growth bands in reef corals, Science, 177, 270-272, 1972.

Lamont-Doherty Earth Observatory, C. U.: Bishop's highresolution (DX) surface solar irradiance derived. Research data archive at the National Center for Atmospheric Research, Computational and Information Systems Laboratory, available at: http://rda.ucar.edu/datasets/ds741.1/ (last access: 4 February 2013), 2000.

Land, L. S.: The fate of reef-derived sediment on the northern Jamaican island slope, Mar. Geol., 29, 55-71, 1979.

Langdon, C., Takahashi, T., Sweeney , C., Chipman, D., Goddard, J., Marubini, F., Aceves, H., Barnett, H., and Atkinson, M., J.: Effect of calcium carbonate saturation state on the calcification rate of an experimental coral reef, Global Biogeochem. Cy., 14, 639-654, 2000.

Lantz, C. A., Atkinson, M. J., Winn, C. W., and Kahng, S. E.: Dissolved inorganic carbon and total alkalinity of a Hawaiian fringing reef: chemical techniques for monitoring the effects of ocean acidification on coral reefs, Coral Reefs, 33, 105-115, 2014.

Locarnini, R. A., Mishonov, A. V., Antonov, J. I., Boyer, T. P., Garcia, H. E., Baranova, O. K., Zweng, M. M., and Johnson, D. R.: World Ocean Atlas 2009, volume 1: temperature, in: NOAA Atlas NESDIS 68, edited by: Levitus, S., U.S. Government Printing Office, Washington, D.C., 1-184, 2010.

Lough, J. M.: Coral calcification from skeletal records revisited, Mar. Ecol. Prog. Ser., 373, 257-264, 2008.

Lough, J. M. and Barnes, D. J.: Environmental controls on growth of the massive coral Porites, J. Exp. Mar. Biol. Ecol., 245, 225243, 2000

Loya, Y., Sakai, K., Yamazato, K., Nakano, Y., Sambali, H., and van Woesik, R.: Coral bleaching: the winners and the losers, Ecol. Lett., 4, 122-131, 2001.
Mallela, J.: Coral reef encruster communities and carbonate production in cryptic and exposed coral reef habitats along a gradient of terrestrial disturbance, Coral Reefs, 26, 775-785, 2007.

Manzello, D. P.: Coral growth with thermal stress and ocean acidification: lessons from the eastern tropical Pacific, Coral Reefs, 29, 749-758, 2010.

Marshall, A. T. and Clode, P.: Calcification rate and the effect of temperature in a zooxanthellate and an azooxanthellate scleractinian reef coral, Coral Reefs, 23, 218-224, 2004.

McClanahan, T. R., Ateweberhan, M., Muhando, C. A., Maina, J., and Mohammed, M. S.: Effects of climate and seawater temperature variation on coral bleaching and mortality, Ecol. Monogr., 77, 503-525, 2007.

McMahon, A., Santos, I. R., Cyronak, T., and Eyre, B. D.: Hysteresis between coral reef calcification and the seawater aragonite saturation state, Geophys. Res. Lett., 40, 4675-4679, 2013.

McNeil, B. I., Matear, R. J., and Barnes, D. J.: Coral reef calcification and climate change: the effect of ocean warming, Geophys. Res. Lett., 31, L22309, doi:10.1029/2004GL021541, 2004.

McWilliams, J. P., Cote, I. M., Gill, J. A., Sutherland, W. J., and Watkinson, A. R.: Accelerating impacts of temperature-induced coral bleaching in the Caribbean, Ecology, 86, 2055-2060, 2005.

Milliman, J. D.: Production and accumulation of calcium carbonate in the ocean: budget of a non-steady state, Global Biogeochem. Cy., 7, 927-957, 1993.

Montaggioni, L. F.: History of Indo-Pacific coral reef systems since the last glaciation: development patterns and controlling factors, Earth-Sci. Rev., 71, 1-75, 2005.

Nakamori, T., Suzuki, A., and Iryu, Y.: Water circulation and carbon flux on Shiraho coral reef of the Ryukyu Islands, Japan, Cont. Shelf Res., 12, 951-970, 1992.

Nakamura, T. and Nakamori, T.: A geochemical model for coral reef formation, Coral Reefs, 26, 741-755, 2007.

Nakamura, T. and Nakamori, T.: Estimation of photosynthesis and calcification rates at a fringing reef by accounting for diurnal variations and the zonation of coral reef communities on reef flat and slope: a case study for the Shiraho reef, Ishigaki Island, southwest Japan, Coral Reefs, 28, 229-250, 2009.

Ohde, S. and van Woesik, R.: Carbon dioxide flux and metabolic processes of a coral reef, Okinawa, Bull. Mar. Sci., 65, 559-576, 1999.

Opdyke, B. N. and Walker, J. C. G.: Return of the coral reef hypothesis: basin to shelf partitioning of $\mathrm{CaCO}_{3}$ and its effect in atmospheric $\mathrm{CO}_{2}$, Geology, 20, 733-736, 1992.

Perry, C. T.: Carbonate budgets and reef framework accumulation, in: Encyclopedia of modern coral reefs: structure, form and process, edited by: Hopley, D., Springer, Netherlands, 185-190, 2011.

Perry, C. T., Spencer, T., and Kench, P. S.: Carbonate budgets and reef production states: a geomorphic perspective on the ecological phase-shift concept, Coral Reefs, 27, 853-866, 2008.

Perry, C. T., Edinger, E. N., Kench, P. S., Murphy, G. N., Smithers, S. G., Steneck, R. S., and Mumby, P. J.: Estimating rates of biologically driven coral reef framework production and erosion: a new census-based carbonate budget methodology and applications to the reefs of Bonaire, Coral Reefs, 31, 853-868, 2012.

Perry, C. T., Murphy, G. N., Kench, P. S., Smithers, S. G., Edinger, E. N., Steneck, R. S., and Mumby, P. J.: Caribbean-wide decline 
in carbonate production threatens coral reef growth, Nature Communications, 4, 1-8, doi:10.1038/ncomms2409, 2013.

Poulsen, A., Burns, K., Lough, J., Brinkman, D., and Delean, S.: Trace analysis of hydrocarbons in coral cores from Saudi Arabia, Org. Geochem., 37, 1913-1930, 2006.

Puverel, S., Tambutte, E., Zoccola, D., Domart-Coulon, I., Bouchot, A., Lotto, S., Allemand, D., and Tambutte, S.: Antibodies against the organic matrix in scleractinians: a new tool to study coral biomineralization, Coral Reefs, 24, 149-156, 2005.

Rayner, N. A., Parker, D. E., Horton, E. B., Folland, C. K., Alexander, L. V., Rowell, D. P., Kent, E. C., and Kaplan, A.: Global analyses of sea surface temperature, sea ice, and night marine air temperature since the late nineteenth century, J. Geophys. Res.Atmos., 108, 4407, doi:10.1029/2002JD002670, 2003.

Reynaud-Vaganay, S., Gattuso, J. P., Cuif, J. P., Jaubert, J., and Juillet-Leclerc, A.: A novel culture technique for scleractinian corals: application to investigate changes in skeletal $\delta 18 \mathrm{O}$ as a function of temperature, Mar. Ecol. Prog. Ser., 180, 121-130, 1999.

Sadd, J. L.: Sediment transport and $\mathrm{CaCO}_{3}$ budget on a fringingreef, Cane Bay, St Croix, United States Virgin Islands, Bull. Mar. Sci., 35, 221-238, 1984.

Schmittner, A., Oschlies, A., Matthews, H. D., and Galbraith, E. D.: Future changes in climate, ocean circulation, ecosystems, and biogeochemical cycling simulated for a business-as-usual $\mathrm{CO}_{2}$ emission scenario until year $4000 \mathrm{AD}$, Global Biogeochem. Cy., 23, Gb3005, doi:10.1029/2009GB003577, 2009.

Scoffin, T. P., Tudhope, A. W., Brown, B. E., Chansang, H., and Cheeney, R. F.: Patterns and possible environmental controls of skeletogenesis of Porites lutea, South Thailand, Coral Reefs, 11, 1-11, 1992.

Shamberger, K. E. F., Feely, R. A., Sabine, C. L., Atkinson, M. J., DeCarlo, E. H., Mackenzie, F. T., Drupp, P. S., and Butterfield, D. A.: Calcification and organic production on a Hawaiian coral reef, Mar. Chem., 127, 64-75, 2011.

Shi, Q., Yu, K. F., Chen, T. R., Zhang, H. L., Zhao, M. X., and Yan, H. Q.: Two centuries-long records of skeletal calcification in massive Porites colonies from Meiji Reef in the southern South China Sea and its responses to atmospheric $\mathrm{CO}_{2}$ and seawater temperature, Science China-Earth Sciences, 55, 1-12, 2012.

Silverman, J., Lazar, B., and Erez, J.: Effect of aragonite saturation, temperature, and nutrients on the community calcification rate of a coral reef, J. Geophys. Res.-Oceans, 112, C05004, doi:10.1029/2006jc003770, 2007.

Silverman, J., Lazar, B., Cao, L., Caldeira, K., and Erez, J.: Coral reefs may start dissolving when atmospheric $\mathrm{CO}_{2}$ doubles, Geophys. Res. Lett., 36, L05606, doi:10.01029/02008g1036282, 2009.

Smith, S. V.: Coral-reef area and the contributions of reefs to processes and resources of the world's oceans, Nature, 273, 225226, 1978.

Smith, S. V. and Harrison, J. T.: Calcium carbonate production of the mare incognitum, the upper windward reef slope, at Enewetak Atoll, Science, 197, 556-559, 1977.
Smith, S. V. and Kinsey, D. W.: Calcium-carbonate production, coral-reef growth, and sea-level change, Science, 194, 937-939, 1976.

Smith, S. V. and Pesret, F.: Processes of carbon dioxide flux in the Fanning Island lagoon, Pac. Sci., 28, 225-245, 1974.

Spalding, M. D. and Grenfell, A. M.: New estimates of global and regional coral reef areas, Coral Reefs, 16, 225-230, 1997.

Spalding, M. D., Ravilious, C., and Green, E. P.: World atlas of coral reefs, Prepared at the UNEP World Conservation Monitoring Centre, University of California Press, Berkeley, USA, 424 pp., 2001.

Stearn, C. W., Scoffin, T. P., and Martindale, W.: Calcium-carbonate budget of a fringing reef on the West coast of Barbados: 1. zonation and productivity, Bull. Mar. Sci., 27, 479-510, 1977.

Steiner, Z., Erez, J., Shemesh, A., Yam, R., Katz, A., and Lazar, B.: Basin-scale estimates of pelagic and coral reef calcification in the Red Sea and Western Indian Ocean, Proceedings of the National Academy of Sciences, 111, 16303-16308, 2014.

Suzuki, A., Nakamori, T., and Kayanne, H.: The mechanisms of production enhancement in coral-reef carbonate systems - model and empirical results, Sediment. Geol., 99, 259-280, 1995.

Tambutté, S., Holcomb, M., Ferrier-Pagès, C., Reynaud, S., Tambutté, É., Zoccola, D., and Allemand, D.: Coral biomineralization: from the gene to the environment, J. Exp. Mar. Biol. Ecol., 408, 58-78, 2011.

Tanzil, J. T., Brown, B. E., Dunne, R. P., Lee, J. N., Kaandorp, J. A., and Todd, P. A.: Regional decline in growth rates of massive Porites corals in Southeast Asia, Glob. Change Biol., 19, 30113023, 2013.

Turley, C., Eby, M., Ridgwell, A. J., Schmidt, D. N., Findlay, H. S., Brownlee, C., Riebesell, U., Fabry, V. J., Feely, R. A., and Gattuso, J.-P.: The societal challenge of ocean acidification, Mar. Pollut. Bull., 60, 787-792, 2010.

Vecsei, A.: Fore-reef carbonate production: development of a regional census-based method and first estimates, Palaeogeogr. Palaeocl., 175, 185-200, 2001.

Vecsei, A.: A new estimate of global reefal carbonate production including the fore-reefs, Global Planet. Change, 43, 1-18, 2004.

Vroom, P. S.: Coral dominance: a dangerous ecosystem misnomer?, J. Mar. Biol., 2011, 164127, doi:10.1155/2011/164127, 2011.

Weaver, A. J., Eby, M., Wiebe, E. C., Bitz, C. M., Duffy, P. B., Ewen, T. L., Fanning, A. F., Holland, M. M., MacFadyen, A., Matthews, H. D., Meissner, K. J., Saenko, O., Schmittner, A., Wang, H. X., and Yoshimori, M.: The UVic Earth system climate model: model description, climatology, and applications to past, present and future climates, Atmos. Ocean, 39, 361-428, 2001.

Wood, S., Paris, C. B., Ridgwell, A., and Hendy, E. J.: Modelling dispersal and connectivity of broadcast spawning corals at the global scale, Global Ecol. Biogeogr., 23, 1-11, 2014. 